\title{
Lysine-Specific Histone Demethylases Contribute to Cellular Differentiation and Carcinogenesis
}

\author{
Gaetano Verde ${ }^{1, *}$, Jessica Querol-Paños ${ }^{2}$, Joan Pau Cebrià-Costa ${ }^{2}$, Laura Pascual-Reguant ${ }^{2}$, \\ Gemma Serra-Bardenys ${ }^{1}$, Ane Iturbide ${ }^{3}$ and Sandra Peiró ${ }^{2, *}$ \\ 1 Programa de Recerca en Càncer, Institut Hospital del Mar d'Investigacions Mèdiques (IMIM), \\ 08003 Barcelona, Spain; gserra@imim.es \\ 2 Vall d'Hebron Institute of Oncology (VHIO), 08035 Barcelona, Spain; jquerol@vhio.net (J.Q.-P.); \\ jcebria@vhio.net (J.P.C.-C.); lpascual@vhio.net (L.P.-R.) \\ 3 Institute of Epigenetics and Stem Cells, Helmholtz Zentrum München, D-81377 München, Germany; \\ ane.iturbide@helmholtz-muenchen.de \\ * Correspondence: gverde@imim.es (G.V.); speiro@vhio.net (S.P.)
}

Academic Editor: Muller Fabbri

Received: 9 February 2017; Accepted: 24 March 2017; Published: 30 March 2017

\begin{abstract}
Histone modifications regulate chromatin structure, gene transcription, and other nuclear processes. Among the histone modifications, methylation has been considered to be a stable, irreversible process due to the slow turnover of methyl groups in chromatin. However, the discovery of three different classes of lysine-specific demethylases-KDM1, Jumonji domain-containing demethylases, and lysyl oxidase-like 2 protein-has drastically changed this view, suggesting a role for dynamic histone methylation in different biological process. In this review, we describe the different mechanisms that these enzymes use to remove lysine histone methylation and discuss their role during physiological (cell differentiation) and pathological (carcinogenesis) processes.
\end{abstract}

Keywords: epigenetics; histone demethylases; cellular differentiation; cancer

\section{Introduction}

Histone N-terminal tails can be post-translationally modified with different chemical groups, including methylation. Histone modifications play key roles in chromatin structure and can influence different DNA processes, such as gene transcription, DNA repair, replication, and recombination. Histones can be methylated on both lysine $(\mathrm{K})$ and arginine $(\mathrm{R})$ residues; however, methylation is most frequently observed on lysine residues of the $\mathrm{H} 3$ and $\mathrm{H} 4$ histone tails [1]. In contrast to other histone modifications, how histone lysine methylation affects gene transcription is strongly dependent upon which amino acid of the peptide is modified. Thus, methylation of lysine 27 (H3K27) or lysine 9 (H3K9) on histone $\mathrm{H} 3$, or of lysine 20 on histone 4 (H4K20), is associated with silenced chromatin [2,3]. In contrast, methylation of lysine 4 on histone 4 (H3K4) is primarily associated with gene activation [4], and methylation of lysine 36 on histone $\mathrm{H} 3$ (H3K36) generally regulates transcriptional elongation [5]. Moreover, so-called bivalent promoters contain both active (H3K4me3) and repressive (H3K27me3) histone methylation [5]. Genes controlled by bivalent promoters, like the Hox genes, are in a poised intermediate state in stem cells. They can be activated or repressed during stem cell differentiation by removing H3K27me3 or H3K4me3, respectively [5]. It was long believed that methylation is an irreversible modification, since the half-lives of histones and the methyl-lysine residues within them are the same [6,7]—in other words, if it is an irreversible modification, the methyl group would be "removed" by natural histone turnover or by dilution after DNA replication. However, during the last decade, different active lysine demethylation mechanisms have been identified. Three different classes of lysine-specific demethylases catalyze these mechanisms: the lysine (K)-specific demethylase 
1 (KDM1A-B, also known as LSD1-2), the Jumonji C domain-containing demethylases (KDM2-7; also known as JHDM), and lysyl oxidase-like 2 (LOXL2). Each of these enzyme groups specifically removes one or more lysine histone methylation groups and plays a key role in gene transcription (Figure 1).

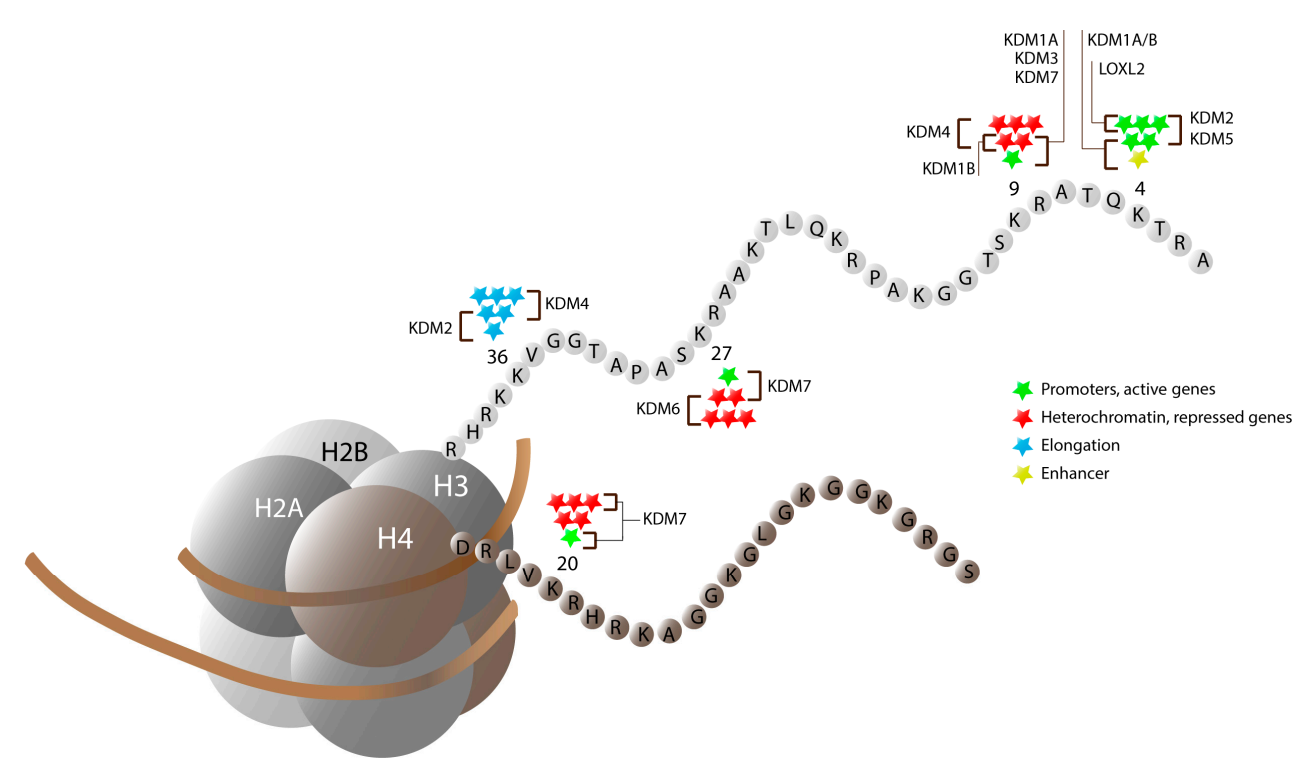

Figure 1. Lysine-specific histone methylation and the activity of histone demethylases. Schematic representation of $\mathrm{H} 3$ and $\mathrm{H} 4$ histone tails, showing the most frequent lysine residues involved in mono-, di-, and trimethylation (stars). The lysine-histone demethylases KDM1A/B, JHDM clusters (KDM2-KDM7), and LOXL2, involved in demethylation of specific methyl markers, are shown.

In this review, we describe the mechanisms that these enzymes use to remove the lysine histone methylation and discuss their roles during both cell differentiation and carcinogenesis.

\section{Lysine-Specific Demethylase 1}

\subsection{KDM1A}

The first histone demethylase to be discovered was KDM1A (also known as LSD1), which removes methylation from mono- and dimethylated lysine 4 (H3K4me1/me2) and lysine 9 of histone 3 (H3K9me1/me2) [8,9]. Based on its sequence analysis, KDM1A is classified as a flavin-dependent monoamine oxidase (MAO) homolog, and it uses the cofactor flavin adenine dinucleotide (FAD) during demethylation catalysis $[8,10]$. The chemistry of the reaction follows the classical amine oxidase scheme: molecular oxygen is consumed during methyl removal to produce formaldehyde and hydrogen peroxide. Two electrons are transferred from the methyl carbon of the dimethylated residue of the histone to the flavin in the form of a hydride anion. Molecular oxygen then reacts with the reduced FAD, generating hydrogen peroxide. The resulting imine-containing peptide is then hydrolyzed, releasing formaldehyde and the demethylated histone 3 [11,12] (Figure 2A). Structurally, KDM1A comprises four domains: an N-terminal disordered segment, a SWIRM (SWI3p, Rsc8p, and Moira) domain, an amine oxidase domain (AOD), and a Tower domain (Figure 2B). The N-terminal disordered segment contains about 150 amino acids and is subjected to post-translational modifications [13-16]. This domain is required for KDM1A nuclear localization and protein-protein interactions $[17,18]$. The SWIRM domain, comprising six $\alpha$ helices and a $3_{10}$ helix, contributes to the structural stability of KDM1A and, compressed against AOD, forms a groove that allows a larger interaction region with the histone 3 tail $[11,19]$. AOD contains the catalytic activity for the demethylation reaction and is divided into two different halves by the Tower domain. The two halves of AOD form a unique globular domain consisting of two lobes. The first lobe, comprising a six-stranded $\beta$-sheet and five $\alpha$ 
helices, enables KDM1A to bind to its substrates [20]. The second lobe allows KDM1A to bind to the FAD cofactor and contains an expanded Rossmann fold, commonly found in dinucleotide binding modules $[10,19]$. Finally, the Tower domain, comprising two helices packed against each other in an antiparallel orientation, protrudes from the catalytic core of the protein. This domain is generally affected by chemical post-translational modifications and is required to allow KDM1A constitutive binding to the co-repressor CoREST1 [21]. The interaction between KDM1A and CoREST1 is essential for KDM1A-dependent demethylation activity [20].

A

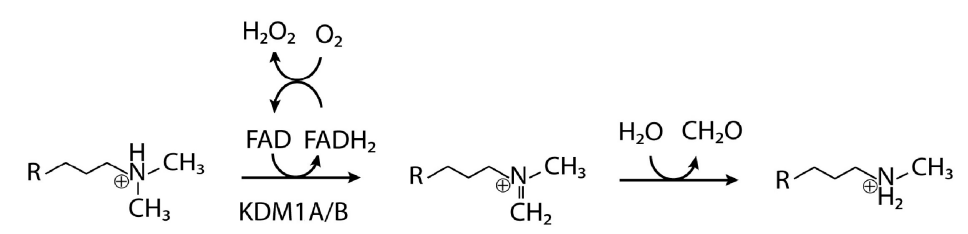

B

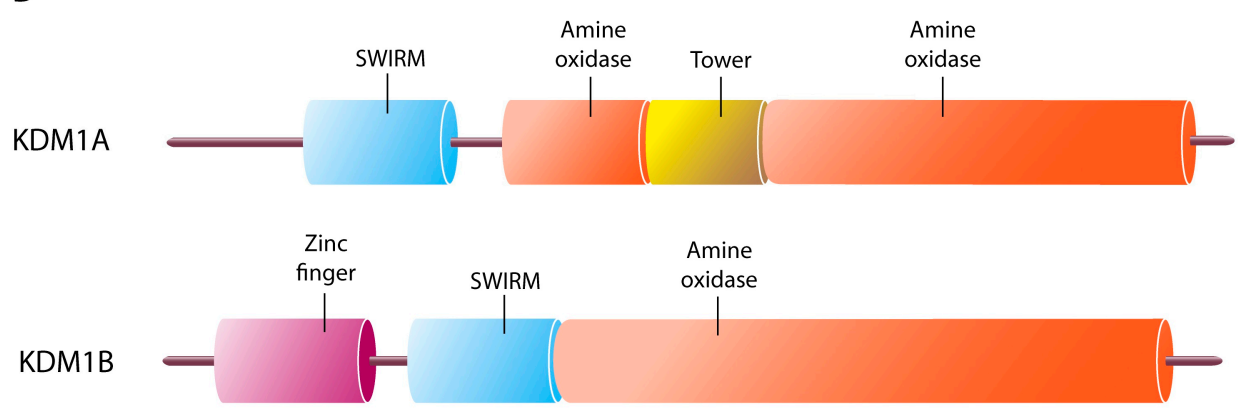

Figure 2. Catalytic mechanism (A) and protein structures (B) of the KDM1 A/B. (A) The amine oxidation reaction used by KDM1A/B depends on flavin adenine dinucleotide (FAD) to demethylate mono- and dimethylated lysine. (B) Schematic representation of KDM1A/B protein structures. SWIRM: SWI3p, Rsc8p, and Moira domain.

\subsection{KDM1A and Long Non-Coding RNA}

Long non-coding RNAs (lncRNAs) are a heterogeneous group of RNAs ranging in length between 200 nucleotides to over $100 \mathrm{~kb}$ [22,23]. During the last decade, a high number of lncRNAs have been identified, many of which are the key regulators of gene transcription and therefore are required for the establishment of cell fate [24,25]. It was recently reported that at least four lncRNAs (Kcnq1ot1, Airn, Xist, and HOTAIR) regulate gene transcription by modifying the histone marks [26-28]. Consistent with these data, many chromatin modifiers contain RNA-binding domains rather than DNA-binding domains [29,30]. KDM1A can associate with different lncRNAs (TERRA, HOTAIR, and steroid receptor-RNA activator, SRA), suggesting a regulatory role for RNA in KDM1A function [28,31]. Interestingly, some lncRNA are able to simultaneously associate with more than one histone modifiers. The lncRNA HOTAIR, for example, has two different domains that bind to the KDM1A/CoREST complex and to the polycomb repressive complex 2 (PRC2), which trimethylates H3K27 [28]. This interaction may be required for coordinating the removal of activating marks by KDM1A/CoREST and the addition of repressive marks by PRC2 on histone. Genome-wide binding analysis reveal that KDM1A and PRC2 co-localize at specific sets of genes, although these proteins do not directly interact with each other, suggesting that both molecular complexes could be recruited to shared target gene by HOTAIR IncRNA [28]. In breast cancer cells, the lncRNA SRA acts as complex scaffold for KDM1A/CoREST. This interaction contributes to repressing key progesterone-inducible genes that must be kept silent in the absence of hormones [31]. Interestingly, biochemical analysis showed that unstructured single-stranded RNA is not able to associate with KDM1A/CoREST. In contrast, when the lncRNA TERRA forms a G-quadruplex (GQ) structure, 
it specifically associates with the functional KDM1A/CoREST complex. Moreover, DNA with a GQ structure is not able to interact with the same molecular complex, suggesting that KDM1A is able to distinguish RNA from DNA [32], although it is still not clear how KDM1A would be able to distinguish between the two nucleic acids.

\subsection{KDM1A and Cellular Differentiation}

KDM1A has different roles in maintaining the cellular phenotype. For instance, it regulates the stem cell state and plays a key role during cellular differentiation processes. Indeed, its depletion from mouse embryonic stem cells (ESCs) leads to increased apoptosis and differentiation impairment [1]. In ESCs, KDM1A is generally bound at enhancer regions of actively transcribed genes, although its demethylase activity is inactivated by the presence of acetylated nucleosomes. During cellular differentiation, in contrast, histone deacetylation by histone deacetylases (HDACs) activates the KDM1A enzymatic activity, leading to demethylation of the genomic regions to which it is bound. Histone hypomethylation, consequently, contributes to inactivating the enhancer genomic regions that control the expression of pluripotency genes. This epigenetic mechanism, known as "enhancer decommissioning", allows cellular differentiation [33].

KDM1A is required for the differentiation of the hematopoietic cell lineage. Comparing the phenotype of KDM1A knock-out mice revealed that KDM1A depletion reduces the levels of terminally differentiated granulocytes and erythrocytes, whereas the levels of their precursors are increased. In this context, KDM1A represses the expression of stem- and progenitor-specific genes by removing the methylation from lysine 4 of histone $3(\mathrm{H} 3 \mathrm{~K} 4)$ at gene promoters and/or enhancer genomic regions that regulate this class of genes. Moreover, KDM1A dually controls erythrocyte differentiation by modulating the expression of the two key transcription factors (GATA1 and GATA2) of this process. In hematopoietic progenitor cells, KDM1A associates with GATA2, thereby allowing GATA1 gene repression. In erythrocyte differentiated cells, KDM1A forms a complex with TAL1 (T-cell acute lymphocytic leukemia 1) in order to repress GATA2 expression [34]. KDM1A contributes to cerebral cortex development. During this process, the complex KDM1A/CoREST interacts with the RBPJ-k protein to negatively regulate the Notch pathway, thereby controlling the transition from neuronal stem cells to differentiated neurons. Indeed, KDM1A depletion in mice impairs neuronal migration [35]. Consistent with these data, KDM1A interacts during Drosophila development with the histone deacetylase SIRT1 to negatively regulate Notch target gene expression by modifying histone modifications [36].

Interestingly, KDM1A has recently been found to be required for brown adipocyte differentiation, as its inhibition or depletion represses brown adipocyte tissue differentiation. Mechanistically, KDM1A demethylates H3K4me1/me2 at promoter regions of Wnt-pathway target genes, activating their expression and promoting brown adipogenesis [37].

Finally, KDM1A is indispensable for the epithelial-to-mesenchymal transition (EMT). EMT refers to the trans-differentiation of epithelial cells into motile mesenchymal cells, which is integral during cancer progression. During this process, epithelial cells lose their junctions and apical-basal polarity, reorganize their cytoskeleton, and undergo a change in their signaling programs that defines cells and enables the development of an invasive phenotype. In this process, KDM1A interacts with the zinc-finger protein SNAIL1 and demethylates $\mathrm{H} 3 \mathrm{~K} 4 \mathrm{me} 1 / \mathrm{me} 2$ at epithelial-specific gene promoters, including that of E-cadherin. The loss of H3K4 methylation represses epithelial-specific gene expression, with a consequent transition to the mesenchymal state $[13,15,38,39]$.

\subsection{KDM1A and Cancer}

Deregulation of KDM1A activity contributes to carcinogenesis of many different cancers, including prostate, bladder, breast, non-small cell lung, colorectal, oral cancers, and neuroblastoma. High levels of this protein often correlate with cancer recurrence and progression [9,40-50]. In hormone-dependent tumors, such as prostrate, bladder, and breast cancer, KDM1A associates with steroid hormone 
receptors (HR) to regulate HR-mediated gene transcription and cell proliferation [9,42-44]. In estrogen receptor (ER)-positive breast cancer cells, for example, KDM1A is recruited by ER $\alpha$ to regulate ER $\alpha$-target gene expression [40]. In this context, deubiquitination of KDM1A by the USP28 protein stabilizes KDM1A structure and confers cancer stem cell-like properties to breast cancer cells, thereby increasing their tumorigenicity [46].

Deregulation of KDM1A expression in non-small cell lung cancer (NSCLC) profoundly alters cell proliferation, migration, and invasion, thereby affecting the EMT process. Indeed, KDM1A overexpression in adenocarcinomic human alveolar basal epithelial cells downregulates epithelial-specific gene expression (e.g., E-cadherin), activates mesenchymal-specific gene expression (e.g., Twist1 and N-cadherin), and increases cell proliferation as well as migration rates [45]. In colorectal and head and neck squamous cancer cells, KDM1A can contribute to tumorigenesis via two different molecular mechanisms: (a) In HCT116 colon cancer cells, it activates Dickkopf-1 (DKK1) gene expression, and the corresponding DKK1 protein negatively regulates the Wnt/ $\beta$-catenin pathway. Repression of the Wnt/ $\beta$-catenin pathway reduces cell differentiation and increases cell proliferation [41]. (b) In colon carcinoma cells, as well as in head and neck squamous cell carcinoma lines, KDM1A demethylates $\mathrm{H} 3 \mathrm{~K} 4 \mathrm{me} 1 / \mathrm{me} 2$ at the E-cadherin gene promoter, repressing its expression [49]. The repression of the E-cadherin gene expression induces the EMT, affecting cell migration and invasion [50,51].

In human neuroblastoma cells, KDM1A is recruited to promoter regions of CDKN1A/p21 and Clusterin (CLU) tumor suppressor genes by the MYC-N protein, where it demethylates H3K4me1/me2 demethylation and thereby reduces $C D K N 1 A / p 21$ and $C L U$ gene expression, leading to increased cell proliferation [48]. Consistent with these data, the micro-RNA 137 (miR-137) in neuroblastoma cells was found to directly target KDM1A mRNA and activate cell properties consistent with tumor suppression [47].

\subsection{KDM1B}

The second protein of the KDM1 histone demethylase cluster is KDM1B (also known as LSD2). KDM1B is classified as a homolog of KDM1A based on its DNA sequence. Although KDM1B shares less than 31\% sequence similarity with KDM1A, it demethylates H3K4me1, H3K4me2, and H3K9me2 through a FAD-dependent amine oxidation reaction (Figure 2A) [8,52]. In contrast to KDM1A, KDM1B does not contain the Tower domain but rather contains a zinc-finger area at its $\mathrm{N}$-terminal region (Figure 2B). This zinc-finger domain or SWIRM motif is indispensable for its demethylation activity $[53,54]$. Genome-wide studies have demonstrated that KDM1B is bound mainly within gene bodies of highly transcribed genes and is almost completely absent from gene promoters [55]. It promotes transcription elongation by interacting with the RNA polymerase II elongating complex and demethylating H3K4me2. The same molecular complex includes the methyltransferases G9A, which monomethylate H3K9, and the nuclear SET domain-containing protein 3 (NSD3), which trimethylate H3K36 [55]. Finally, the NPAC/GLYR1 protein, a putative H3K36me3 reader, can interact with KDM1B to enhance its H3K4 demethylation activity [56]. Interestingly, in addition to its role in transcriptional elongation, KDM1B was found to induce gene derepression in mouse dentric cells by removing the methyl group from $\mathrm{H} 3 \mathrm{~K} 9 \mathrm{me} 2$ at NF- $\mathrm{KB}$ target gene promoters [57].

KDM1B plays key roles during embryo development, and embryos derived from KDM1B-depleted oocytes die before mid-gastrulation. This maternal-lethal effect is most probably due to the role of KDM1B in the establishment of genomic imprinting [58]. Indeed, this enzyme is mainly expressed in oocytes, where, through its H3K4 demethylation activity, it enables de novo DNA methylation in several imprinted genes (genes expressed in a parent-of-origin-specific manner) [58]. Finally, KDM1B inhibits lung cancer cell growth independently from its demethylase activity [54]. The zinc finger domain of KDM1B catalyzes the ubiquitylation of O-GlcNAc transferase (OGT) and induces its degradation. OGT degradation, in turn, reduces oncogene expression and promotes tumor cell growth [54]. The finding that the histone demethylases KDM1B has E3 ligase activity raises the question of a possible connection between histone demethylase and ubiquitin-dependent pathway. 


\section{Jumonji C Domain-Containing Proteins}

The second and largest class of demethylase enzymes contains a Jumonji C (JmjC) domain and catalyzes lysine demethylation of histones through an oxidative reaction that requires iron $\mathrm{Fe}(\mathrm{II})$ and $\alpha$-ketoglutarate $(\alpha K G)$ as cofactors [59]. Unlike KDM1 demethylases, which can only remove mono- and/or dimethyl lysine modifications, the JmjC domain-containing histone demethylases (JHDMs) can remove all three histone lysine methylation states. Various studies of $\alpha$ KG-dependent oxygenases suggest the following reaction mechanism: First, the enzyme binds iron (Fe) through its metal-binding motif HXD/EXnH, the so-called facial triad. Next, the Fe(II) enzyme complex binds the cofactor $\alpha K G$, and subsequently the substrate and oxygen. Oxygen binding is followed by the oxidative decarboxylation of $\alpha \mathrm{KG}$ to produce succinate, carbon dioxide, and ferryl. The latter is a highly reactive group and can potentially oxidize a $\mathrm{C}-\mathrm{N}$ bond in a lysine-methyl group, forming an unstable carbinolamine that will rapidly break down, leading to the release of formaldehyde and loss of a methyl group from lysine (Figure 3A).

A

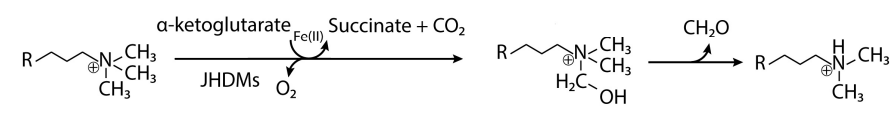

B
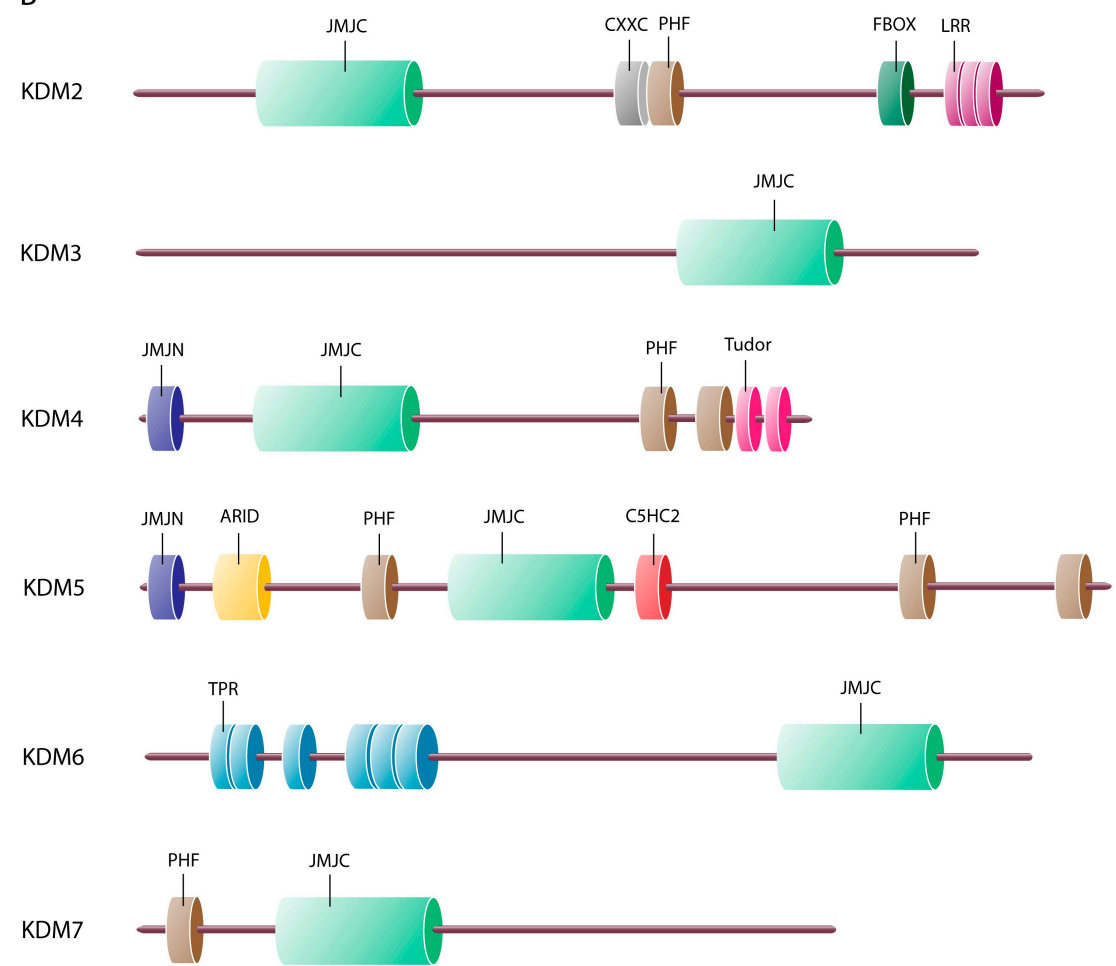

Figure 3. Catalytic mechanism (A) and protein structures (B) of the JHDM (JmjC domain-containing histone demethylase; KDM2-KDM7) enzymes. (A) The JHDM family (KDM2-KDM7) with the two cofactors (iron ion, $\mathrm{Fe}(\mathrm{II})$, and $\alpha$-ketoglutarate, $\alpha \mathrm{KG}$ ) uses a dioxygenase reaction to demethylate lysine histones. (B) Schematic protein structure representation of the different clusters (KDM2-KDM7) of JHDM proteins. JmjC, Jumonji C domain; PHF, PHD finger; LRR, leucine-rich repeat; TPR, tetratricopeptide.

Structurally, these enzymes contains different domains: in addition to the JmjC domain, they can have PHD finger, Bright/Arid, C5HC2, CXXC, Tudor, F-box, leucine-rich repeat (LRR), and tetratricopeptide-like (TPR) domains (Figure 3B). 
The JmjC domain is structurally conserved and has a similar structure in all of the JHDMs [60]. It folds into eight $\beta$-sheets to form an ezymatically active pocket that coordinates $\mathrm{Fe}(\mathrm{II})$ and $\alpha \mathrm{KG}$ binding, essential for the demethylase activity [61]. The PHD finger domain is required to bind both methylated and unmethylated histones; the Bright/Arid and the $\mathrm{C} 5 \mathrm{HC} 2$ domains enable JHDMs' binding to DNA, and the Tudor domain allows the binding to the H3K4me3 mark [62-64]. The F-box, LRR, and TPR domains mediate protein-protein interactions and are required to form multiprotein complexes [65-67]. The substrate specificity of each JHDM, finally, seems to rely on both the JmjC domain and the specific additional domains found within each protein [61]. How the JmjC domain cooperates with other domains to regulate histone modifications is still unclear [68].

There are 27 different JmjC-containing proteins in the human genome that can be grouped into different subfamilies depending on their structure and function. Here, we describe the specific roles of the six JmjC clusters (KDM2-KDM7) during cellular differentiation and carcinogenesis (Table 1).

\subsection{JmjC-Containing Proteins and Cellular Differentiation}

\subsubsection{KDM2 Cluster (FBXL Subfamily)}

In addition to their roles in different signaling pathways, histone modifications are essential during mesenchymal stem cell (MSC) differentiation [69]. Two proteins belong to this cluster: KDM2A (FBXL11) and KDM2B (FBXL10). KDM2A was the first discovered JmjC domain-containing protein able to erase mono- and di-methyl marks from lysine 36 of histone 3 (H3K36me1/me2) [70]. KDM2B, in contrast, is responsible not only for demethylating H3K36me1/me2 but also for removing the methyl mark from H3K4me3 [71]. Both demethylases regulate MSC differentiation through their association with the BCL-6 co-repressor (BCOR) complex [72]. KDM2A interacts with BCOR and inhibits odontogenic differentiation of human stem cells from apical papilla (SCAPs), a type of dental MSC [72]. In addition, the KDM2A/BCOR complex inhibits osteogenesis by reducing the epiregulin (EREG) gene transcription through the demethylation of $\mathrm{H} 3 \mathrm{~K} 4 \mathrm{me} 3$ or $\mathrm{H} 3 \mathrm{~K} 36 \mathrm{me} 1 / \mathrm{me} 2$ from its promoter. Epiregulin is a key transcription factor required for the expression of osteogenic-related genes, such as osterix (OSX) and distal-less homeobox 5 (DLX5) [73]. Consistent with these data, KDM2A depletion in SCAPs enhances adipogenic differentiation in vitro [74]. Similarly, in MSCs, the KDM2B/BCOR complex contributes to osteogenesis differentiation by repressing AP- $2 \alpha$ (activating enhancer-binding protein $2 \alpha$ ) gene expression through the demethylation of H3K4me3 and H3K36me2 from its promoter [72].

Finally, KDM2B impairs adipogenesis by recruiting the polycomb repressive complex 1 (PRC1) to repress key genes (e.g., Cdk1, Uhrf1, Pparg1, and Pparg2) required for the conversion of pluripotent cells into the adipogenic lineage. Interestingly, KDM2B-dependent adipogenesis inhibition is independent from the demethylase activity of the protein; however, its F-box and leucine-rich repeat domains are required for recruiting a noncanonical PRC1 containing the RING1B, SKP1, PCGF1, and BCOR proteins [75].

\subsubsection{KDM3 Cluster (JMJD1 Subfamily)}

Methylation of lysine 9 of histone 3 (H3K9me1/me2/me3) is an epigenetic mark associated with gene repression, and the level of this mark strongly correlates with cell state differentiation. The neural progenitors cells (NPCs), for instance, have lower H3K9 methylation levels than the undifferentiated ESCs [76]. The loss of this epigenetic mark by the KDM3A member JMJD1A is crucial for maintaining ESC self-renewal and for various cell differentiation processes, including spermiogenesis and vascular smooth muscle cell differentiation.

In ESCs, KDM3A contributes to self-renewal maintenance by preventing the H3K9 dimethylation at pluripotency-associated gene promoters (e.g., the Tcl1 gene) [77-80]. During spermiogenesis, KDM3A binds to and positively regulates the expression of two genes, transition nuclear protein (Tnp1) and protamine 1 (Prm1), by removing the repressive H3K9 marks from their promoters. During sperm 
chromatin maturation, the Tnp1 and Prm1 proteins play key roles in the histone replacement process. Indeed, sperm cells from $K d m 3 a$ gene-trap mice exhibit post-meiotic chromatin condensation defects, with a low number of mature sperm cells, suggesting that KDM3A could be a good candidate gene for azoospermia and globozoospermia (two clinical syndromes characterized by spermatogenesis defects) [81]. Similar to KDM3A, KDM3C (JMJD1C) is expressed in a sex- and stage-specific manner in the germline when changes in chromatin architecture take place [81]. A series of knockout studies have demonstrated that both proteins play essential roles in male gametogenesis. Indeed, their depletion severely affects the formation of functional gametes and fertility [81].

KDM3A also contributes to smooth muscle cell (SMC) differentiation. The myocardin transcription factor interacts with KDM3A and recruits it to SMC-specific gene promoters. KDM3A subsequently demethylates $\mathrm{H} 3 \mathrm{~K} 9 \mathrm{me} 3$ from these genomic regions and regulates their TGFß-mediated activation [82].

KDM3B (JMJD1B) displays histone H3K9me1/me2 demethylase activity, and different pieces of evidence suggest that it plays a role in leukemogenesis, via activation of $l m o 2$ through interdependent actions with the histone acetyltransferase (HAT) complex containing CBP. Consistent with these data, KDM3B expression induces leukemic transformation by inhibiting leukemia cell differentiation and is upregulated in blood cells obtained from certain types of leukemia patients [82].

KDM3C (JMJD1C), finally, is required for the correct formation of dendritic cells. Mutations of this enzyme have been reported in patients affected by intellectual disability, such as Rett syndrome. Further, mutations of this enzyme in HEK 293 affects the KDM3C demethylation activity, impairing the loss of methylation of MDC1 protein required to repair DNA damage. Consequently, the mutated $\mathrm{KDM} 3 \mathrm{C}$ protein affects the cell response to DNA damage [83].

\subsubsection{KDM4 Cluster (JMJD2 Subfamily)}

The KDM4 cluster catalyzes the removal of di- and tri-methyl marks of H3K9 (H3K9me2/me3) and H3K36 (H3K36me2/me3) [69]. The members of this cluster that contribute to embryonic development and cell differentiation are KDM4A, $-4 \mathrm{~B}$, and -4C. KDM4A (JMJD2A) is crucial for muscle differentiation, inducing Myog gene expression by demethylating the $\mathrm{H} 3 \mathrm{~K} 9 \mathrm{me} 2$ and $\mathrm{H} 3 \mathrm{~K} 9 \mathrm{me} 3$ on its promoter [84]. In human MSCs, in contrast, KDM4B (JMJD2B) removes the H3K9me3 mark at the DLX5 gene promoter, allowing osteoblast differentiation [69]. Different studies have suggested that KDM4B is required during adipogenesis; however, its role in this process is still controversial. Ye et al. (2012) found that KDM4B reduces adipogenic lineage specification from MSCs [85]. Guo et al. (2012), on the other hand, demonstrated that KDM4B can promote preadipocyte differentiation, acting as a cofactor of the $\mathrm{C} / \mathrm{EBP} \beta$ protein [86]. Further studies are required to clarify the role of KDM4B during adipogenesis.

In contrast to KDM4B, KDM4C (JMJD2C) is induced during adipocyte differentiation, and depletion of KDM4C is sufficient to block this kind of cellular differentiation [87]. However, the molecular mechanism by which KDM4C contributes to this process is still not clear. Finally, in ESCs, KDM4C is required to maintain the euchromatic status of Nanog gene promoter by removing H3K9me3 mark. Further, H3K9 demethylation prevents binding of transcription co-repressors, including heterochromatin protein 1 (HP1) and KRAB-associated protein 1 (KAP1), to Nanog gene promoter [88].

Finally, while KDM4D (JMJD2D) is absent in different tissues, it is highly expressed in spermatocytes and spermatids; however, its role during spermatogenesis is still unknown [89]. Mutant $K D M 4 D$ male mice have globally higher levels of $\mathrm{H} 3 \mathrm{~K} 9 \mathrm{me} 3$ than control mice, yet they are as fertile as control mice [89]. In contrast, this demethylase is required for the inflammatory response of macrophages and dendritic cells. In this context, KDM4D demethylates the H3K9me3 levels at the enhancer regions that control the expression of $M d c$ and $I l 12 b$ genes, enabling their expression during the inflammatory response [90]. Interestingly, it was recently reported that KDM4D is able to bind RNA through two distinct RNA-binding domains, one of which is the JmjC domain. The KDM4D binding to RNA is independent of KDM4D demethylase activity and is required for its association with 
chromatin [91]. Whether all the JmjC-containing proteins require RNA for their enzymatic activity as well as for their association with chromatin is still unknown and should be clarified by further studies.

\subsubsection{The KDM5 Cluster (JARID1 Subfamily)}

The members of this cluster-KDM5A (JARID1A), KDM5B (JARID1B), and KDM5C (JARID1C) demethylate H3K4me2/me3, thereby acting as transcriptional repressors [92]. As for the other JHDMs proteins, the KDM5 cluster is also implicated in eukaryotic cellular differentiation and development [93]. KDM5A binds to Hox genes and represses their transcription in undifferentiated ESCs [92]. During retinoic acid differentiation of ESCs, however, it is displaced from Hox genes, leading to an increase of H3K4me3 levels at their promoters. The increased levels of this epigenetic mark induce Hox gene expression in the differentiated cells [92]. On the other hand, KDM5A affects osteogenic differentiation of human adipose-derived stem cells, occupying the promoters of the osteogenesis-associated genes OSX and OC to maintain the levels of H3K4me3 [94].

KDM5B acts as a co-repressor of specific transcription factors required during embryonic development [95]. It binds to and modulates the transcriptional activity of BF-1 (brain factor) and Pax9 (paired box 9), two transcription factors that play key roles during neural cell differentiation and craniofacial development, respectively [96].

Finally, evidence suggests that KDM5C is required for brain development. Indeed, the KDM5C gene is expressed specifically in the brain during development and is frequently mutated in X-linked mental retardation [97]. However, whether KDM5C is essential for brain development, and how it could play this role, are still unknown.

\subsubsection{KDM6 Cluster (UTX/JMJD3 Subfamily)}

$K D M 6 A$ (UTX) is a X-linked chromosome gene encoding an ubiquitously expressed protein that controls the basal levels of $\mathrm{H} 3 \mathrm{~K} 27 \mathrm{me} 3$ and the induction of ectoderm differentiation, and it is essential for somatic cell reprogramming $[98,99]$. KDM6B (JMJD3), in contrast, is induced upon inflammation or exposure to viral or oncogenic stimuli $[100,101]$. It controls neuronal and epidermal differentiation and inhibits reprogramming [102]. In addition, both KDM6A and KDM6B have key roles in MSC lineage specification. Interestingly, in contrast to KDM5A, KDM6A induces the expression of three key genes (RUNX2, Osteopontin, and Osteocalcin) that are required for osteoblast differentiation, by removing the H3K27me3 mark from their promoters [103]. Similarly, KDM6B (together with KDM4B) demethylates $\mathrm{H} 3 \mathrm{~K} 27 \mathrm{me} 3$ from the $B M P$ (bone morphogenetic protein) and HOX gene promoters, inducing osteogenic differentiation of MSCs [85,104]. Finally, these proteins are involved in the inhibition of adipogenic differentiation of MSCs: depletion of KDM6B or KDM4B in human bone marrow-derived MSCs enhances adipogenesis and decreases osteogenic differentiation [85]. However, the mechanism(s) underlying their role in this process are still unknown.

KDM6C (UTY) is Y-linked chromosome gene that belongs to H3K27me3 demethylase family, although its demethylase activity is still debated [105]. Surprisingly, KDM6C and KDM6A activate gene expression during embryonic development by associating with RBBP5, a subunit of the H3K4 methyltransferase complex. Thus, in contrast to the other JmjC containing proteins, these enzymes participate in H3K4 methyltransferase activity rather than in histone demethylation [105].

\subsubsection{The KDM7 Cluster}

The recently identified KDM7 cluster includes KDM7A (PHF8), KDM7B (KIAA1718), and KDM7C (PHF2), which activate gene transcription by demethylating H3K9me2/me1, H3K27me2/me1, and H4K20me1 [106]. During zebrafish neuronal differentiation and craniofacial development, KDM7A induces MSX gene expression. The MSX gene family encodes homeodomain transcription factors that act downstream of the transforming growth factor beta (TGF $\beta$ ), BMP, and Wnt-signaling pathways essential in craniofacial and neural development [107]. 
In mouse ESCs, KDM7B is required for neural differentiation, as it removes the H3K9me2 and H3K27me2 from the FGF4 gene promoter. FGF4 (fibroblast growth factor 4), in turn, phosphorylates the extracellular signal-regulated kinases 1 and 2 (ERK1 and ERK2, respectively), thereby allowing neural fate determination [108]. Additionally, KDM7C is required for osteoblast differentiation and bone development: its overexpression in mice enhances bone development, whereas its depletion in rats protracts calvarial bone regeneration [109]. Moreover, KDM7C modulates the function of Runx2 (Runt-related transcription factor 2), a key protein required for osteoblast differentiation during bone development. Interestingly, through its JmjC domain, KDM7C interacts with Runx2 and reduces its lysyl methylation level. The loss of Runx2's post-translational modifications enhances its DNA binding capability, thereby modifying the Runx2-mediated gene transcription [109].

\subsection{JmjC Proteins and Cancer}

The JmjC-containing proteins regulate different processes that contribute to tumor development, including genome stability and cell senescence. Several genetic alterations of Jumonji family genes have been described in human cancers $[95,106]$. However, the specific role of these proteins in cancer is largely debated in literature. Depending on the tumor type, the great majority of JmjC-containing proteins could act either as tumor suppressors or as oncogenes.

\subsubsection{The KDM2 Cluster (FBXL Subfamily)}

KDM2A (FBXL11) has tumor suppressor properties in transformed mouse embryonic fibroblasts, fibrosarcoma, and prostate and colon cancer cells [110-112]. However, the same gene is overexpressed in breast, gastric, and lung cancers, promoting tumorigenesis both in cell lines and mouse xenografts [113-115]. Interestingly, KDM2A represses migration and invasion of breast cancer cells, and inhibits angiogenic tubule formation by endothelial cells [116]. The same authors also found that KDM2A can bind to $\mathrm{Rb}$ and E2F1 proteins and repress the transcriptional activity of E2F1. KDM2B (FBXL10) was first proposed to have tumor suppressor properties, as its expression is reduced in different cancers, such as in aggressive brain tumors, and its presence is required to maintain genome stability in these cancer types [71,117]. However, in human pancreatic ductal adenocarcinoma, KDM2B is overexpressed and promotes tumorigenesis. In this type of cancer, KDM2B interacts with the Polycomb proteins, c-Myc, and KDM5A, and regulates the expression of developmental and metabolic genes [118]. In addition, KDM2B could act as a critical epigenetic factor for leukemogenesis. The $K D M 2 B$ gene is overexpressed in leukemias, and ectopic expression of this protein contributes to hematopoietic progenitor cell proliferation allowing leukemic transformation. Indeed, in leukemia stem cells, KDM2B contributes to repressing the expression of the tumor suppressor p $15^{\mathrm{Ink} 4}$ gene by removing the methylation mark H3K36me2 from its promoter [119].

\subsubsection{The KDM3 Cluster (JMJD1 Subfamily)}

KDM3A (JMJD1A) is expressed at significantly higher levels in breast, colon, and renal cancers than in normal tissue [120-122]. Under hypoxia conditions, KDM3A increases renal and colon tumor growth by inducing the expression of a subset of hypoxia-inducible genes (including adrenodemullin and GDF15 [growth and differentiation factor 15]). The induction of hypoxia-inducible gene expression is due to the KDM3A-mediated reduction of the methylation marks H3K9me1/me2 [123]. Frequent deletion of $5 \mathrm{q} 31$, which contains the KDM3B (JMJD1B) gene, or reduced expression of KDM3C (JMJD1C), in various malignancies suggests possible roles of these proteins in tumor suppression [123]. KDM3C has been proposed to be an important driver of MLL-AF9 and HOXA9-driven leukemias. In this context, KDM3C directly interacts with HOXA9 and modulates a HOXA9-controlled gene expression program. Depletion of KDM3C in mice reduces the frequency of leukemia stem cells and causes differentiation of MLL-AF9- and HOXA9-driven leukemias [124]. In addition to its roles in leukemias, KDM3C levels are decreased in breast tumors, where it specifically coactivates androgen receptor and responds to alterations in systemic androgen levels [125]. 


\subsubsection{The KDM4 Cluster (JMJD2 Subfamily)}

Tri- and dimethylation of lysine 9 on histone H3 (H3K9me3/me2) enable heterochromatin protein 1 (HP1) binding and are generally associated with gene repression. The members of the KDM4 cluster are overexpressed in prostate cancer, where they widely remove the methylation marks from $\mathrm{H} 3 \mathrm{~K} 9 \mathrm{me} 3 / \mathrm{me}$. The loss of $\mathrm{H} 3 \mathrm{~K} 9 \mathrm{me} 3$ enables HP1a delocalization, with a consequent reduction in heterochromatin [126]. Moreover, KDM4C (JMJD2C) is amplified or upregulated in several cell lines derived from oesophageal squamous carcinomas, medulloblastoma, and breast cancer [126-130]. In addition, in agreement with a contribution of KDM4C to tumor development, inhibition of KDM4C expression reduces cell proliferation [126].

KDM4A (JMJD2A) regulates gastric cancer growth and serves as an independent prognostic factor. The depletion of this protein induces apoptosis of gastric cancer cells by upregulating the expression of pro-apoptotic proteins and microRNA (miR-34a) and by downregulating anti-apoptotic proteins. Importantly, KDM4A expression is associated with tumor stage and nodal status, and high levels of this protein predict poor overall and disease-free survival [131].

\subsubsection{The KDM5 Cluster (JARID1 Subfamily)}

KDM5A (JARID1A) promotes gastric cancer cell growth and is enriched in drug-resistant lung cancer cells. The depletion of this protein from lung cancer tissues, indeed, drastically affects cell proliferation, motility, migration, invasion, and metastasis [132] In this context, KDM5A binds to integrin-b1 (ITGB1) promoters and induces its expression. Integrin-b1, in turn, plays key roles in lung cancer metastasis. Simultaneously, KDM5A induces the expression of cyclins D1 and E1 while suppressing the expression of cyclin-dependent kinase inhibitor p27 (CDKN1B), each contributing to KDM5A-mediated cell proliferation [132,133]. Besides its roles in gastric and lung cancer, KDM5A has been suggested to contribute, through its interaction with retinoblastoma protein $(\mathrm{pRb})$, to uncontrolled growth in malignant melanomas. Indeed, KDM5A expression is downregulated in advanced and metastatic melanomas. Further, the great majority of benign melanocytic nevi are KDM5A positive, whereas $90 \%$ of primary malignant melanomas and $70 \%$ of melanoma metastases were found to lack this protein [134]. In agreement with in vivo data, melanoma cell lines exhibit low and heterogeneous levels of KDM5A expression [134].

KDM5B (JARID1B) has been described as a putative oncogene in several cancers, and its level of expression is correlated with tumor malignancy [135-138]. The KDM5B-mediated H3K4 demethylase activity plays an important role in the proliferative capacity of breast cancer cells through repression of tumor suppressor genes, including BRCA1 [135-138]. Similar to breast cancer, KDM5B is upregulated also in prostate cancer tissues as compared to benign prostate samples. In this context, KDM5B associates with androgen receptor and regulates its transcriptional activity [138]. On the other hand, knockdown of KDM5B in hepatocellular carcinoma cells (HCCs) inhibits cell proliferation via cell cycle arrest at the G1/S phase. In this case, KDM5B induces the expression of key cell regulatory genes (e.g., p15 and p27) by removing the methylation mark of histone H3K4me3 from their promoters [139]. Consistent with these data, KDM5B overexpression in HCCs increases proliferation, EMT, migration, and invasion in vitro, and enhances tumorigenic and metastatic capacities in vivo [137].

Finally, KDM5C (JARID1C) is upregulated in prostate cancers, where it regulates proliferationassociated genes [140]. In vitro, KDM5C depletion enhances the expression of several proliferationassociated genes and impairs prostate cancer cell growth [140]. KDM5C localizes in heterochromatin, leading to the demethylation of $\mathrm{H} 3 \mathrm{~K} 4 \mathrm{me} 3$ and enhancing the deposition of $\mathrm{H} 3 \mathrm{~K} 9 \mathrm{me} 3$ on chromocenters by SUV39H1. When KDM5C is mutated, an increased expression of heterochromatic noncoding RNAs (ncRNAs) triggers genomic instability, leading to clear cell renal cell carcinoma (ccRCC) [141]. 


\subsubsection{The KDM6 Cluster (UTX/JMJD3 Subfamily)}

KDM6A (UTX) functions as a tumor suppressor and is frequently genetically inactivated in many tumors, including lung, liver, renal, bladder, colorectal, and T-cell acute lymphoblastic leukemia (T-ALL) [142-145]. Interestingly, KDM6A and KDM6B (JMJD3) have opposing roles in the context of the same tumor. KDM6B is required for the initiation and maintenance of T-ALL by regulating key oncogenic gene targets by demethylating H3K27me3 [144]. KDM6A, in contrast, is frequently inactivated in T-ALL and has a tumor suppressor role [144]. Beside its role in T-ALL, KDM6B has different functions depending on the tumor types: it is downregulated in lymphomas, leukemias, lung, liver, colon, colorectal, pancreatic cancers, and gliomas [100,146-148], whereas it is upregulated in some melanomas, gliomas, lymphomas, myelodysplastic syndrome, and prostate cancers [149-155]. In addition, it was recently demonstrated that the expression of KDM6B is significant higher in ccRCC tissue as compared with non-tumor tissue, and increased KDM6B expression positively correlates with cancer stage, tumor size, and lymph node metastasis [156]. Furthermore, high levels of KDM6B expression positively correlate with poor prognosis. Finally, KDM6B can cause EMT by inducing the expression of the master transcription factor SLUG [156].

\subsubsection{The KDM7 Cluster}

The histone demethylase KDM7A (PHF8) is overexpressed and works as an oncoprotein in many cancers, including prostate and non-small cell lung cancer, leukemia, and esophageal squamous cell carcinoma [157]. In many of these tumors, high KDM7A expression is significantly associated with shorter overall survival and disease-free survival. KDM7A depletion from prostate cancer cell lines decreases cell proliferation and migration with a simultaneously significant increase of apoptosis, demonstrating that KDM7A is indispensable for prostate cancer proliferation and metastasis [158]. Consistent with these data, substantial evidence indicates that modulation of KDM7A expression regulates the transcription of genes related to cell cycle and cytoskeletal dynamics [159-162]. Among these, KDM7A induces microRNA miR-21 gene expression and, interestingly, miR-21 depletion impedes the KDM7A effects on proliferation and apoptosis of lung cancer cells, demonstrating that the role of KDM7A during these processes is mediated by miR-21 microRNA [158]. Moreover, KDM7A is required for the retinoic acid response of acute promyelocytic leukemia. It was demonstrated, indeed, that all-trans retinoic acid (ATRA) sensitivity depends on the histone demethylation activity of KDM7A, suggesting that the pharmacological regulation of PHF8 activity can be useful to restore the ATRA sensitivity to resistant cells [163]. In contrast to the oncogenic role of KDM7A, KDM7C (PHF2) could have tumor suppressor role during cancer development. It interacts with p53 protein in cancer cells and demethylates $\mathrm{H} 3 \mathrm{~K} 9 \mathrm{me} 2$ at p53 target genes, allowing p53-dependent apoptosis under genotoxic stress [164].

\section{Lysyl Oxidase-Like 2}

The lysyl oxidase-like 2 (LOXL2) enzyme belongs to the lysyl oxidase family, comprising the lysyl oxidase (LOX) and four lysyl oxidase-like proteins (LOXL1-4). These enzymes are amine oxidases able to remove the amino group located in the $\varepsilon$-position of lysine residues through oxidation, leaving an aldehyde group as a product of the reaction. They require two cofactors to catalyze the reaction, copper and quinone [165] (Figure 4A).

Structurally, the C-terminal regions of LOX proteins contain all the elements required for their enzymatic activity: a copper-binding motif, residues for lysine tyrosylquinone cofactor formation, and a cytokine receptor-like domain. The $\mathrm{N}$-terminal domain, in contrast, gives sequence variability to each member of the family protein and, except for LOXL1, the other LOXL members (LOXL2/3/4) also contain four scavenger receptor cysteine-rich (SRCR) domains that are commonly found in cell surface receptors and adhesion molecules [166] (Figure 4B). Although this family was first known to crosslink collagen and elastin in the extracellular matrix, nuclear-related functions have been described for some 
of the members $[167,168]$. LOXL2 specifically removes the amino group from trimethylated lysine 4 in histone H3 (H3K4me3). The proposed model for this reaction involves the nucleophilic attack by the water-derived hydroxide ion to lysine $C \varepsilon$. The reaction produces triethylamine and alcohol [169]. The alcohol is then oxidized twice by the active site of LOXL2 (lysine tyrosylquinone; LTQ) [170], releasing hydrogen peroxide and an aldehyde group in the product lysine (allysine) (Figure 4A). This new histone modification is referred as H3K4ox [169]. Since LOXL2 removes an active epigenetic mark, such as H3K4me3, it generally acts as a transcriptional repressor.

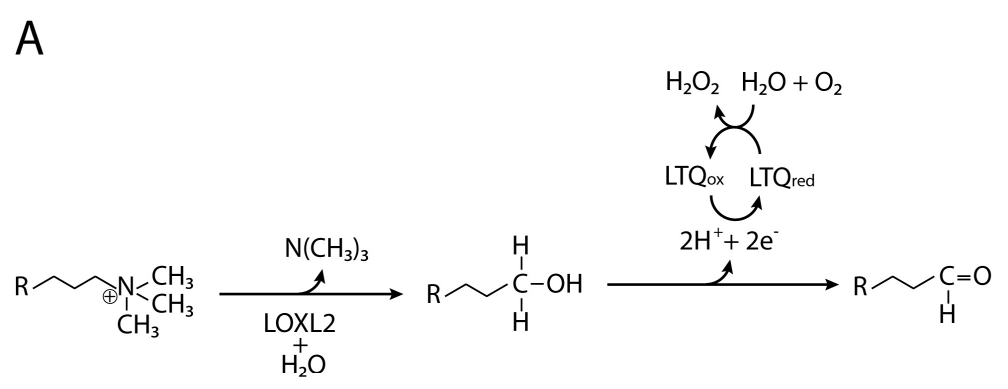

B

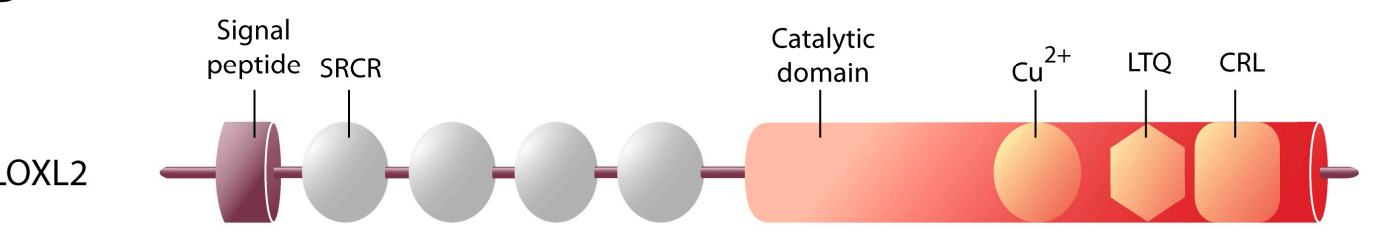

Figure 4. (A) Proposed chemical reaction model for H3K4me3 deamination by LOXL2. LTQox, oxidated lysine tyrosylquinone; LTQred, reduced lysine tyrosylquinone. (B) Schematic representation of LOXL2 protein structure. SRCR, scavenger receptor cysteine-rich domain; $\mathrm{Cu}^{2+}$, copper-binding domain; LTQ, lysine tyrosylquinone domain; CRL, cytokine receptor-like.

\subsection{LOXL2 and Cellular Differentiation}

Different studies have linked LOXL2 expression to cell differentiation. LOXL2 transcription, for instance, is downregulated during keratinocyte differentiation [171]. Concomitantly, the progression of skin squamous carcinoma cells (cells characterized by aberrant differentiation) is associated with enhanced LOXL2 expression [172]. In addition, while LOX, LOXL1, LOXL3, and LOXL4 levels are increased in adult human dental pulp stem cells (hDPSCs) that differentiate to odontoblast-like cells, LOXL2 is reduced at both mRNA and protein levels during the same process. Consistently, the inhibition of LOXL2 activity promotes hDPSC differentiation to odontoblasts [173]. In contrast, LOXL2 expression increases significantly during chondrocyte differentiation, and its depletion abolishes chondrocyte differentiation [174].

Recently, a new role for LOXL2 during ESC differentiation has been described [175]. When ESCs exit the pluripotency state upon retinoic acid treatment, LOXL2 oxidizes the TAF10 transcription factor (a subunit of either the TFIID general transcription factor complex and of the SAGA histone acetyltransferase complex) and represses the pluripotency core network. In addition, LOXL2 depletion in zebrafish affects embryo development, leading to overexpression of the Oct4 pluripotency factor and a failed neural commitment development [175].

Finally, EMT inductors, such as hypoxia and TGF $\beta$, promote Loxl2 gene expression $[176,177]$, and the LOXL2 protein, in turn, interacts and stabilizes the SNAIL1 transcription factor to repress epithelial-specific gene promoters [176,177]. 


\subsection{LOXL2 and Cancer}

LOXL2 has been proposed to regulate tumor cell survival, chemoresistance, cell adhesion, motility, and invasion, and to remodel the tumor microenvironment [166]. Different human cancers show an LOXL2 up-regulation $[178,179]$ that correlates with tumor grade, poor prognosis, and decreased survival [168]. In fact, a possible role for LOXL2 in pre-metastatic niche formation has been suggested [180]. Further, LOXL2 can modify the extracellular matrix components in the tumor microenvironment and metastatic niche of HCCs and promote intrahepatic metastasis by increasing tissue stiffness, thereby enhancing the cytoskeletal reorganization of HCC cells [180] Additionally, LOXL2 facilitates extrahepatic metastasis by enhancing recruitment of bone marrow-derived cells to the metastatic site [180]. Finally, since LOXL2 plays a key role during EMT (as described above), alterations of LOXL2 could increase the metastatic progression of cancer cells by affecting this process. Further studies are required to investigate this possibility.

\section{Beyond the Histone Demethylase Function}

Besides their role as histone demethylases, lysine-specific demethylases can remove methyl groups from non-histone proteins in order to regulate their function and/or stability. Moreover, some of them can have others enzymatic activities independent of their demethylation function.

During carcinogenesis, KDM1A interacts with the tumor suppressor protein p53 and demethylates its lysine 370, preventing p53 from interacting with the coactivator binding protein 1 (53BP1) [181]. The absence of a p53-53BP1 molecular complex inhibits the p53 transcriptional activity and enhances the tumor cell growth [181]. The same histone demethylase is required for gastrulation during mouse embryogenesis by removing methyl groups from lysine 1096 on DNA methyltransferases 1 (DNMT1) [182]. The KDM1A-mediated demethylation of DNMT1 increases its stability and provides a mechanistic link between the histone and DNA methylation systems [182]. Similar to KDM1A, KDM6B is able to demethylate p53 but, in this case, the p53 demethylation stabilizes the protein, allowing p53 to accumulate in the nucleus [183]. KDM1A can also demethylate the transcription factor E2F1 and the myosin phosphatase target subunit 1 (MYPT1) [184,185]. E2F1 demethylation by KDM1A in p53-deficient cells is crucial for the DNA damage-induced cell death [184], whereas demethylation of MYPT1 at lysine 442 induces MYPT1 degradation, such that the retinoblastoma protein $(\mathrm{Rb})$ is persistently phosphorylated and supports cell progression [185]. KDM2A negatively regulates the nuclear factor NF- $\mathrm{kB}$ through the demethylation of lysine 218 and 221 on the p65 subunit [112]. Besides the role of NF- $\mathrm{KB}$ in inflammation and innate immunity, a role for it in cancer initiation and progression has also been reported [186]. In addition, as mentioned above, LOXL2 plays a key role in the balance between pluripotency and differentiation of ESCs by demethylating non-histone proteins. For instance, it oxidizes methylated transcription factor TAF10 and regulates TFIID-dependent genes expression during neural progenitor differentiation [175].

In contrast to the other histone demethylases, KDM1B has an E3 ubiquitin ligase activity that is independent of its demethylase function. Through its polyubiquitylation of the O-GlcNAc transferase OGT, KDM1B induces the OGT proteasomal degradation. OGT is often upregulated in cancer, and loss of KDM1B E3 ligase activity leads to activation of different classes of oncogenes, demonstrating that KDM1B may act as a suppressor of tumorigenesis through its E3 ligase activity and its effects on OGT stability [54].

Finally, besides their enzymatic activities, some of the lysine-specific demethylases can act as molecular scaffolds to target chromatin modifiers to specific genomic regions. KDM2B, for instance, is able to bind to $\mathrm{CpG}$ island regions (DNA regions in which the frequency of the CG sequence is higher than in other regions) through its Zn-finger CxxC DNA-binding domain, where it can recruit PRC1 to these genomic regions $[187,188]$. PRC1, in turn, can ubiquitinate lysine 119 of histone H2A, leading to a closing of the chromatin structure $[46,189]$. Similarly, KDM3A and KDM6 demethylases play a role in chromatin remodeling by linking transcription factors with the SWI/SNF chromatin remodeling complex $[190,191]$. Since these proteins regulate the chromatin compaction associated with 
genes involved in carcinogenesis and cell proliferation, mutation or depletion of histone demethylases could interfere with these biological processes.

\section{Conclusions}

Several mechanistic classes of lysine-specific histone demethylases have been identified in the last decade and have been found to have activities crucial for the regulation of gene expression. These enzymes are involved in important processes, such as cell cycle and cell differentiation, and misregulation of these enzymes can have an enormous impact on cell behavior. Due to the link between this enzymatic activity and cancer, and to the latest discoveries about the structural and biochemical properties of these enzymes, they have become potential drug targets for cancer treatment. However, it is essential to keep in mind that these enzymes are not only involved in cancers but also have critical physiological roles in gene regulation and genome organization, such that altering their activity might have far-reaching negative (and yet unknown) consequences.

Table 1. Lysine-specific histone demethylases and their related cellular differentiation processes and putative roles in cancer.

\begin{tabular}{|c|c|c|c|c|}
\hline Names & Cellular Differentiation & Ref. & Putative Cancer Role & Ref. \\
\hline KDM1A & $\begin{array}{l}\text { Hematopoiesis, cerebral cortex development, } \\
\text { brown adipogenesis, EMT }\end{array}$ & [24-30] & Oncogene & [31-40] \\
\hline KDM1B & Embryo development & {$[58]$} & Tumor suppressor & {$[54]$} \\
\hline KDM2A & $\begin{array}{l}\text { Osteo/dentinogenic differentiation, } \\
\text { adipogenesis }\end{array}$ & [88-90] & $\begin{array}{l}\text { Pro- and anti-oncogenic } \\
\text { functions }\end{array}$ & [126-132] \\
\hline KDM2B & Osteogenesis; adipogenesis & {$[88,91]$} & $\begin{array}{l}\text { Pro- and anti-oncogenic } \\
\text { functions }\end{array}$ & {$[87,133-135]$} \\
\hline KDM3A & $\begin{array}{l}\text { Spermatogenesis; smooth muscle } \\
\text { cell differentiation }\end{array}$ & {$[97,98]$} & Oncogene & [136-139] \\
\hline KDM3B & Leukemogenesis & {$[98,140]$} & Tumor suppressor & [139] \\
\hline KDM3C & Neurogenesis? & [99] & Tumor suppressor & [139-141] \\
\hline KDM4A & Skeletal muscle cell differentiation & [100] & Oncogene & {$[142,147]$} \\
\hline KDM4B & Osteoblast differentiation; adipogenesis & {$[85,101,102]$} & Oncogene & [142] \\
\hline KDM4C & Adipogenesis & {$[103]$} & Oncogene & [142-146] \\
\hline KDM4D & Spermatogenesis? & [105] & NR & \\
\hline KDM5A & Osteogenesis & [110] & $\begin{array}{l}\text { Pro- and anti-oncogenic } \\
\text { functions }\end{array}$ & {$[136,148-150]$} \\
\hline KDM5B & $\begin{array}{l}\text { Neural cell differentiation, craniofacial } \\
\text { and development }\end{array}$ & {$[111,112]$} & Oncogene & {$[151-154]$} \\
\hline KDM5C & Brain development & [113] & Oncogene & {$[156,157]$} \\
\hline KDM6A & $\begin{array}{l}\text { Ectoderm differentiation; cell reprogramming; } \\
\text { osteoblast differentiation }\end{array}$ & {$[114,115,119]$} & Tumor suppressor & [158-161] \\
\hline KDM6B & $\begin{array}{l}\text { Neuronal and epidermal differentiation; } \\
\text { cell reprogramming; osteogenic and } \\
\text { adipogenic differentiation }\end{array}$ & {$[101,118,120]$} & $\begin{array}{l}\text { Pro- and anti-oncogenic } \\
\text { functions }\end{array}$ & {$[116,160,162-172]$} \\
\hline KDM7A & $\begin{array}{l}\text { Neuronal differentiation, } \\
\text { craniofacial development }\end{array}$ & [123] & Oncogene & [173-178] \\
\hline KDM7B & Neuronal differentiation & {$[124]$} & NR & \\
\hline KDM7C & Osteoblast differentiation; bone formation & [125] & Tumor suppressor & [180] \\
\hline LOXL2 & $\begin{array}{l}\text { Keratinogenesis; odontoblast genesis; } \\
\text { chondrogenesis; zebrafish development; EMT }\end{array}$ & {$[171,173-177]$} & Oncogene & {$[166,178-180]$} \\
\hline
\end{tabular}

$$
\text { NR, not reported. EMT, epithelial-mesenchymal transition. }
$$

Acknowledgments: This work was supported by grants from Instituto de Salud Carlos III (ISCIII) FIS/FEDER (PI12/01250; CP08/00223), Red Temática de Investigación Cooperativa en Cáncer (RTICC, RD012/0036/005), and Fundació La Marató TV3. G.V. has received funding from MINECO, the "Juan de la Cierva Incorporation" fellowship (ref. IJCI-2014-20723). S.P. was a recipient of a Miguel Servet contract (ISCIII/FIS), and J.P.C., L.P.-R., and G.S.B. are supported by contracts from Fundació La Marató, ISCII, and a FPU Fellowship from MINECO, respectively. G.V. would like to thank Aldo Verde for his support. 
Author Contributions: Gaetano Verde and Sandra Peiró contributed equally to this review paper.

Conflicts of Interest: The authors declare no conflicts of interest.

\section{References}

1. Wang, Y.; Jia, S. Degrees make all the difference: The multifunctionality of histone H4 lysine 20 methylation. Epigenetics 2009, 4, 273-276. [CrossRef] [PubMed]

2. Cao, R.; Wang, L.; Wang, H.; Xia, L.; Erdjument-Bromage, H.; Tempst, P.; Jones, R.S.; Zhang, Y. Role of histone h3 lysine 27 methylation in polycomb-group silencing. Science 2002, 298, 1039-1043. [CrossRef] [PubMed]

3. Schotta, G.; Lachner, M.; Sarma, K.; Ebert, A.; Sengupta, R.; Reuter, G.; Reinberg, D.; Jenuwein, T. A silencing pathway to induce H3-K9 and H4-K20 trimethylation at constitutive heterochromatin. Genes Dev. 2004, 18, 1251-1262. [CrossRef] [PubMed]

4. Bernstein, B.E.; Kamal, M.; Lindblad-Toh, K.; Bekiranov, S.; Bailey, D.K.; Huebert, D.J.; McMahon, S.; Karlsson, E.K.; Kulbokas, E.J., 3rd; Gingeras, T.R.; et al. Genomic maps and comparative analysis of histone modifications in human and mouse. Cell 2005, 120, 169-181. [CrossRef] [PubMed]

5. Harikumar, A.; Meshorer, E. Chromatin remodeling and bivalent histone modifications in embryonic stem cells. EMBO Rep. 2015, 16, 1609-1619. [CrossRef] [PubMed]

6. Byvoet, P.; Shepherd, G.R.; Hardin, J.M.; Noland, B.J. The distribution and turnover of labeled methyl groups in histone fractions of cultured mammalian cells. Arch. Biochem. Biophys. 1972, 148, 558-567. [CrossRef]

7. Duerre, J.A.; Lee, C.T. In vivo methylation and turnover of rat brain histones. J. Neurochem. 1974, 23, 541-547. [CrossRef] [PubMed]

8. Shi, Y.; Lan, F.; Matson, C.; Mulligan, P.; Whetstine, J.R.; Cole, P.A.; Casero, R.A.; Shi, Y. Histone demethylation mediated by the nuclear amine oxidase homolog LSD1. Cell 2004, 119, 941-953. [CrossRef] [PubMed]

9. Metzger, E.; Wissmann, M.; Yin, N.; Muller, J.M.; Schneider, R.; Peters, A.H.; Gunther, T.; Buettner, R.; Schule, R. LSD1 demethylates repressive histone marks to promote androgen-receptor-dependent transcription. Nature 2005, 437, 436-439. [CrossRef] [PubMed]

10. Yang, M.; Gocke, C.B.; Luo, X.; Borek, D.; Tomchick, D.R.; Machius, M.; Otwinowski, Z.; Yu, H. Structural basis for corest-dependent demethylation of nucleosomes by the human LSD1 histone demethylase. Mol. Cell 2006, 23, 377-387. [CrossRef] [PubMed]

11. Forneris, F.; Binda, C.; Vanoni, M.A.; Mattevi, A.; Battaglioli, E. Histone demethylation catalysed by LSD1 is a flavin-dependent oxidative process. FEBS Lett. 2005, 579, 2203-2207. [CrossRef] [PubMed]

12. Karasulu, B.; Patil, M.; Thiel, W. Amine oxidation mediated by lysine-specific demethylase 1: Quantum mechanics/molecular mechanics insights into mechanism and role of lysine 661. J. Am. Chem. Soc. 2013, 135, 13400-13413. [CrossRef] [PubMed]

13. Peng, B.; Wang, J.; Hu, Y.; Zhao, H.; Hou, W.; Zhao, H.; Wang, H.; Liao, J.; Xu, X. Modulation of LSD1 phosphorylation by CK2/WIP1 regulates RNF168-dependent 53BP1 recruitment in response to DNA damage. Nucleic Acids Res. 2015, 43, 5936-5947. [CrossRef] [PubMed]

14. Costa, R.; Arrigoni, G.; Cozza, G.; Lolli, G.; Battistutta, R.; Izpisua Belmonte, J.C.; Pinna, L.A.; Sarno, S. The lysine-specific demethylase 1 is a novel substrate of protein kinase CK2. Biochim. Biophys. Acta 2014, 1844, 722-729. [CrossRef] [PubMed]

15. Feng, J.; Xu, G.; Liu, J.; Zhang, N.; Li, L.; Ji, J.; Zhang, J.; Zhang, L.; Wang, G.; Wang, X.; et al. Phosphorylation of LSD1 at Ser112 is crucial for its function in induction of emt and metastasis in breast cancer. Breast Cancer Res. Treat. 2016, 159, 443-456. [CrossRef] [PubMed]

16. Li, Y.; Wan, X.; Wei, Y.; Liu, X.; Lai, W.; Zhang, L.; Jin, J.; Wu, C.; Shao, Q.; Shao, G.; et al. LSD1-mediated epigenetic modification contributes to ovarian cancer cell migration and invasion. Oncol. Rep. 2016, 35, 3586-3592. [CrossRef] [PubMed]

17. Jin, Y.; Kim, T.Y.; Kim, M.S.; Kim, M.A.; Park, S.H.; Jang, Y.K. Nuclear import of human histone lysine-specific demethylase LSD1. J. Biochem. 2014, 156, 305-313. [CrossRef] [PubMed]

18. Metzger, E.; Willmann, D.; McMillan, J.; Forne, I.; Metzger, P.; Gerhardt, S.; Petroll, K.; Von Maessenhausen, A.; Urban, S.; Schott, A.K.; et al. Assembly of methylated KDM1A and CHD1 drives androgen receptor-dependent transcription and translocation. Nat. Struct. Mol. Biol. 2016, 23, 132-139. [CrossRef] [PubMed] 
19. Lee, M.G.; Wynder, C.; Cooch, N.; Shiekhattar, R. An essential role for corest in nucleosomal histone 3 lysine 4 demethylation. Nature 2005, 437, 432-435. [CrossRef] [PubMed]

20. Tochio, N.; Umehara, T.; Koshiba, S.; Inoue, M.; Yabuki, T.; Aoki, M.; Seki, E.; Watanabe, S.; Tomo, Y.; Hanada, M.; et al. Solution structure of the swirm domain of human histone demethylase LSD1. Structure 2006, 14, 457-468. [CrossRef] [PubMed]

21. Luo, H.; Shenoy, A.K.; Li, X.; Jin, Y.; Jin, L.; Cai, Q.; Tang, M.; Liu, Y.; Chen, H.; Reisman, D.; et al. MOF acetylates the histone demethylase LSD1 to suppress Epithelial-to-Mesenchymal transition. Cell Rep. 2016, 15, 2665-2678. [CrossRef] [PubMed]

22. Carninci, P.; Kasukawa, T.; Katayama, S.; Gough, J.; Frith, M.C.; Maeda, N.; Oyama, R.; Ravasi, T.; Lenhard, B.; Wells, C.; et al. The transcriptional landscape of the mammalian genome. Science 2005, 309, 1559-1563. [PubMed]

23. Dinger, M.E.; Pang, K.C.; Mercer, T.R.; Mattick, J.S. Differentiating protein-coding and noncoding RNA: Challenges and ambiguities. PLoS Comput. Biol. 2008, 4, e1000176. [CrossRef] [PubMed]

24. Dinger, M.E.; Amaral, P.P.; Mercer, T.R.; Pang, K.C.; Bruce, S.J.; Gardiner, B.B.; Askarian-Amiri, M.E.; Ru, K.; Solda, G.; Simons, C.; et al. Long noncoding RNAs in mouse embryonic stem cell pluripotency and differentiation. Genome Res. 2008, 18, 1433-1445. [CrossRef] [PubMed]

25. Loewer, S.; Cabili, M.N.; Guttman, M.; Loh, Y.H.; Thomas, K.; Park, I.H.; Garber, M.; Curran, M.; Onder, T.; Agarwal, S.; et al. Large intergenic non-coding RNA-ROR modulates reprogramming of human induced pluripotent stem cells. Nat. Genet. 2010, 42, 1113-1117. [CrossRef] [PubMed]

26. Pandey, R.R.; Mondal, T.; Mohammad, F.; Enroth, S.; Redrup, L.; Komorowski, J.; Nagano, T.; Mancini-Dinardo, D.; Kanduri, C. Kcnq1ot1 antisense noncoding RNA mediates lineage-specific transcriptional silencing through chromatin-level regulation. Mol. Cell 2008, 32, 232-246. [CrossRef] [PubMed]

27. Nagano, T.; Mitchell, J.A.; Sanz, L.A.; Pauler, F.M.; Ferguson-Smith, A.C.; Feil, R.; Fraser, P. The Air noncoding RNA epigenetically silences transcription by targeting G9a to chromatin. Science 2008, 322, 1717-1720. [CrossRef] [PubMed]

28. Tsai, M.C.; Manor, O.; Wan, Y.; Mosammaparast, N.; Wang, J.K.; Lan, F.; Shi, Y.; Segal, E.; Chang, H.Y. Long noncoding RNA as modular scaffold of histone modification complexes. Science 2010, 329, 689-693. [CrossRef] [PubMed]

29. Bernstein, E.; Allis, C.D. Rna meets chromatin. Genes Dev. 2005, 19, 1635-1655. [CrossRef] [PubMed]

30. Sun, Y.; Zhang, H. A unified mode of epigenetic gene silencing: RNA meets polycomb group proteins. RNA Biol. 2005, 2, 8-10. [CrossRef] [PubMed]

31. Vicent, G.P.; Nacht, A.S.; Zaurin, R.; Font-Mateu, J.; Soronellas, D.; Le Dily, F.; Reyes, D.; Beato, M. Unliganded progesterone receptor-mediated targeting of an RNA-containing repressive complex silences a subset of hormone-inducible genes. Genes Dev. 2013, 27, 1179-1197. [CrossRef] [PubMed]

32. Hirschi, A.; Martin, W.J.; Luka, Z.; Loukachevitch, L.V.; Reiter, N.J. G-quadruplex RNA binding and recognition by the lysine-specific histone demethylase-1 enzyme. RNA 2016, 22, 1250-1260. [CrossRef] [PubMed]

33. Whyte, W.A.; Bilodeau, S.; Orlando, D.A.; Hoke, H.A.; Frampton, G.M.; Foster, C.T.; Cowley, S.M.; Young, R.A. Enhancer decommissioning by LSD1 during embryonic stem cell differentiation. Nature 2012, 482, 221-225. [CrossRef] [PubMed]

34. Guo, Y.; Fu, X.; Huo, B.; Wang, Y.; Sun, J.; Meng, L.; Hao, T.; Zhao, Z.J.; Hu, X. GATA2 regulates GATA1 expression through LSD1-mediated histone modification. Am. J. Transl. Res. 2016, 8, 2265-2274. [PubMed]

35. Lopez, C.I.; Saud, K.E.; Aguilar, R.; Berndt, F.A.; Canovas, J.; Montecino, M.; Kukuljan, M. The chromatin modifying complex corest/LSD1 negatively regulates notch pathway during cerebral cortex development. Dev. Neurobiol. 2016, 76, 1360-1373. [CrossRef] [PubMed]

36. Mulligan, P.; Yang, F.; Di Stefano, L.; Ji, J.Y.; Ouyang, J.; Nishikawa, J.L.; Toiber, D.; Kulkarni, M.; Wang, Q.; Najafi-Shoushtari, S.H.; et al. A SIRT1-LSD1 corepressor complex regulates Notch target gene expression and development. Mol. Cell 2011, 42, 689-699. [CrossRef] [PubMed]

37. Chen, Y.; Kim, J.; Zhang, R.; Yang, X.; Zhang, Y.; Fang, J.; Chen, Z.; Teng, L.; Chen, X.; Ge, H.; et al. Histone demethylase LSD1 promotes adipocyte differentiation through repressing wnt signaling. Cell Chem. Biol. 2016, 23, 1228-1240. [CrossRef] [PubMed] 
38. Lin, T.; Ponn, A.; Hu, X.; Law, B.K.; Lu, J. Requirement of the histone demethylase LSD1 in Snai1-mediated transcriptional repression during epithelial-mesenchymal transition. Oncogene 2010, 29, 4896-4904. [CrossRef] [PubMed]

39. Lin, Y.; Wu, Y.; Li, J.; Dong, C.; Ye, X.; Chi, Y.I.; Evers, B.M.; Zhou, B.P. The snag domain of snail1 functions as a molecular hook for recruiting lysine-specific demethylase 1. EMBO J. 2010, 29, 1803-1816. [CrossRef] [PubMed]

40. Bennesch, M.A.; Segala, G.; Wider, D.; Picard, D. Lsd1 engages a corepressor complex for the activation of the estrogen receptor alpha by estrogen and camp. Nucleic Acids Res. 2016, 44, 8655-8670. [CrossRef] [PubMed]

41. Huang, Z.; Li, S.; Song, W.; Li, X.; Li, Q.; Zhang, Z.; Han, Y.; Zhang, X.; Miao, S.; Du, R.; et al. Lysine-specific demethylase 1 (LSD1/KDM1A) contributes to colorectal tumorigenesis via activation of the Wnt/ $\beta$-catenin pathway by down-regulating Dickkopf-1 (DKK1) [corrected]. PLoS ONE 2013, 8, e70077. [CrossRef]

42. Kahl, P.; Gullotti, L.; Heukamp, L.C.; Wolf, S.; Friedrichs, N.; Vorreuther, R.; Solleder, G.; Bastian, P.J.; Ellinger, J.; Metzger, E.; et al. Androgen receptor coactivators lysine-specific histone demethylase 1 and four and a half LIM domain protein 2 predict risk of prostate cancer recurrence. Cancer Res. 2006, 66, 11341-11347. [CrossRef] [PubMed]

43. Kashyap, V.; Ahmad, S.; Nilsson, E.M.; Helczynski, L.; Kenna, S.; Persson, J.L.; Gudas, L.J.; Mongan, N.P. The lysine specific demethylase-1 (LSD1/KDM1A) regulates VEGF-A expression in prostate cancer. Mol. Oncol. 2013, 7, 555-566. [CrossRef] [PubMed]

44. Kauffman, E.C.; Robinson, B.D.; Downes, M.J.; Powell, L.G.; Lee, M.M.; Scherr, D.S.; Gudas, L.J.; Mongan, N.P. Role of androgen receptor and associated lysine-demethylase coregulators, LSD1 and JMJD2A, in localized and advanced human bladder cancer. Mol. Carcinog. 2011, 50, 931-944. [CrossRef] [PubMed]

45. Lv, T.; Yuan, D.; Miao, X.; Lv, Y.; Zhan, P.; Shen, X.; Song, Y. Over-expression of LSD1 promotes proliferation, migration and invasion in non-small cell lung cancer. PLoS ONE 2012, 7, e35065. [CrossRef] [PubMed]

46. Wu, Y.; Wang, Y.; Yang, X.H.; Kang, T.; Zhao, Y.; Wang, C.; Evers, B.M.; Zhou, B.P. The deubiquitinase USP28 stabilizes LSD1 and confers stem-cell-like traits to breast cancer cells. Cell Rep. 2013, 5, 224-236. [CrossRef] [PubMed]

47. Althoff, K.; Beckers, A.; Odersky, A.; Mestdagh, P.; Koster, J.; Bray, I.M.; Bryan, K.; Vandesompele, J.; Speleman, F.; Stallings, R.L.; et al. MiR-137 functions as a tumor suppressor in neuroblastoma by downregulating KDM1A. Int. J. Cancer 2013, 133, 1064-1073. [CrossRef] [PubMed]

48. Amente, S.; Milazzo, G.; Sorrentino, M.C.; Ambrosio, S.; Di Palo, G.; Lania, L.; Perini, G.; Majello, B. Lysine-specific demethylase (LSD1/KDM1A) and mycn cooperatively repress tumor suppressor genes in neuroblastoma. Oncotarget 2015, 6, 14572-14583. [CrossRef] [PubMed]

49. Ding, J.; Zhang, Z.M.; Xia, Y.; Liao, G.Q.; Pan, Y.; Liu, S.; Zhang, Y.; Yan, Z.S. LSD1-mediated epigenetic modification contributes to proliferation and metastasis of colon cancer. Br. J. Cancer 2013, 109, 994-1003. [CrossRef] [PubMed]

50. Wang, Y.; Zhu, Y.; Wang, Q.; Hu, H.; Li, Z.; Wang, D.; Zhang, W.; Qi, B.; Ye, J.; Wu, H.; et al. The histone demethylase LSD1 is a novel oncogene and therapeutic target in oral cancer. Cancer Lett. 2016, 374, 12-21. [CrossRef] [PubMed]

51. Kim, S.A.; Inamura, K.; Yamauchi, M.; Nishihara, R.; Mima, K.; Sukawa, Y.; Li, T.; Yasunari, M.; Morikawa, T.; Fitzgerald, K.C.; et al. Loss of CDH1 (E-cadherin) expression is associated with infiltrative tumour growth and lymph node metastasis. Br. J. Cancer 2016, 114, 199-206. [CrossRef] [PubMed]

52. Karytinos, A.; Forneris, F.; Profumo, A.; Ciossani, G.; Battaglioli, E.; Binda, C.; Mattevi, A. A novel mammalian flavin-dependent histone demethylase. J. Biol. Chem. 2009, 284, 17775-17782. [CrossRef] [PubMed]

53. Yang, Z.; Jiang, J.; Stewart, M.D.; Qi, S.; Yamane, K.; Li, J.; Zhang, Y.; Wong, J. Aof1 is a histone H3K4 demethylase possessing demethylase activity-independent repression function. Cell Res. 2010, 20, $276-287$. [CrossRef] [PubMed]

54. Yang, Y.; Yin, X.; Yang, H.; Xu, Y. Histone demethylase LSD2 acts as an E3 ubiquitin ligase and inhibits cancer cell growth through promoting proteasomal degradation of OGT. Mol. Cell 2015, 58, 47-59. [CrossRef] [PubMed]

55. Fang, R.; Barbera, A.J.; Xu, Y.; Rutenberg, M.; Leonor, T.; Bi, Q.; Lan, F.; Mei, P.; Yuan, G.C.; Lian, C.; et al. Human LSD2/KDM1B/AOF1 regulates gene transcription by modulating intragenic H3K4me2 methylation. Mol. Cell 2010, 39, 222-233. [CrossRef] [PubMed] 
56. Fang, R.; Chen, F.; Dong, Z.; Hu, D.; Barbera, A.J.; Clark, E.A.; Fang, J.; Yang, Y.; Mei, P.; Rutenberg, M.; et al. LSD2/KDM1B and its cofactor NPAC/GLYR1 endow a structural and molecular model for regulation of H3K4 demethylation. Mol. Cell 2013, 49, 558-570. [CrossRef] [PubMed]

57. Van Essen, D.; Zhu, Y.; Saccani, S. A feed-forward circuit controlling inducible NF-kappab target gene activation by promoter histone demethylation. Mol. Cell 2010, 39, 750-760. [CrossRef] [PubMed]

58. Ciccone, D.N.; Su, H.; Hevi, S.; Gay, F.; Lei, H.; Bajko, J.; Xu, G.; Li, E.; Chen, T. Kdm1b is a histone H3K4 demethylase required to establish maternal genomic imprints. Nature 2009, 461, 415-418. [CrossRef] [PubMed]

59. Tsukada, Y.; Fang, J.; Erdjument-Bromage, H.; Warren, M.E.; Borchers, C.H.; Tempst, P.; Zhang, Y. Histone demethylation by a family of jmjc domain-containing proteins. Nature 2006, 439, 811-816. [CrossRef] [PubMed]

60. Chen, Z.; Zang, J.; Whetstine, J.; Hong, X.; Davrazou, F.; Kutateladze, T.G.; Simpson, M.; Mao, Q.; Pan, C.H.; Dai, S.; et al. Structural insights into histone demethylation by JMJD2 family members. Cell 2006, 125, 691-702. [CrossRef] [PubMed]

61. Klose, R.J.; Kallin, E.M.; Zhang, Y. JMJC-domain-containing proteins and histone demethylation. Nat. Rev. Genet. 2006, 7, 715-727. [CrossRef] [PubMed]

62. Iwase, S.; Lan, F.; Bayliss, P.; de la Torre-Ubieta, L.; Huarte, M.; Qi, H.H.; Whetstine, J.R.; Bonni, A.; Roberts, T.M.; Shi, Y. The x-linked mental retardation gene SMCX/JARID1C defines a family of histone H3 lysine 4 demethylases. Cell 2007, 128, 1077-1088. [CrossRef] [PubMed]

63. Shi, X.; Hong, T.; Walter, K.L.; Ewalt, M.; Michishita, E.; Hung, T.; Carney, D.; Pena, P.; Lan, F.; Kaadige, M.R.; et al. ING2 PHD domain links histone H3 lysine 4 methylation to active gene repression. Nature 2006, 442, 96-99. [CrossRef] [PubMed]

64. Wysocka, J.; Swigut, T.; Xiao, H.; Milne, T.A.; Kwon, S.Y.; Landry, J.; Kauer, M.; Tackett, A.J.; Chait, B.T.; Badenhorst, P.; et al. A PHD finger of NURF couples histone H3 lysine 4 trimethylation with chromatin remodelling. Nature 2006, 442, 86-90. [CrossRef] [PubMed]

65. D'Andrea, L.D.; Regan, L. TPR proteins: The versatile helix. Trends Biochem. Sci. 2003, 28, 655-662. [CrossRef] [PubMed]

66. Bai, C.; Sen, P.; Hofmann, K.; Ma, L.; Goebl, M.; Harper, J.W.; Elledge, S.J. SKP1 connects cell cycle regulators to the ubiquitin proteolysis machinery through a novel motif, the F-box. Cell 1996, 86, 263-274. [CrossRef]

67. Kobe, B.; Kajava, A.V. The leucine-rich repeat as a protein recognition motif. Curr. Opin. Struct. Biol. 2001, 11, 725-732. [CrossRef]

68. Yang, Y.; Hu, L.; Wang, P.; Hou, H.; Lin, Y.; Liu, Y.; Li, Z.; Gong, R.; Feng, X.; Zhou, L.; et al. Structural insights into a dual-specificity histone demethylase CEKDM7A from Caenorhabditis elegans. Cell Res. 2010, 20, 886-898. [CrossRef] [PubMed]

69. Deng, P.; Chen, Q.M.; Hong, C.; Wang, C.Y. Histone methyltransferases and demethylases: Regulators in balancing osteogenic and adipogenic differentiation of mesenchymal stem cells. Int. J. Oral Sci. 2015, 7, 197-204. [CrossRef] [PubMed]

70. Rotili, D.; Mai, A. Targeting histone demethylases: A new avenue for the fight against cancer. Genes Cancer 2011, 2, 663-679. [CrossRef] [PubMed]

71. Frescas, D.; Guardavaccaro, D.; Bassermann, F.; Koyama-Nasu, R.; Pagano, M. JHDM1B/FBXL10 is a nucleolar protein that represses transcription of ribosomal RNA genes. Nature 2007, 450, 309-313. [CrossRef] [PubMed]

72. Fan, Z.; Yamaza, T.; Lee, J.S.; Yu, J.; Wang, S.; Fan, G.; Shi, S.; Wang, C.Y. BCOR regulates mesenchymal stem cell function by epigenetic mechanisms. Nat. Cell Biol. 2009, 11, 1002-1009. [CrossRef] [PubMed]

73. Du, J.; Ma, Y.; Ma, P.; Wang, S.; Fan, Z. Demethylation of epiregulin gene by histone demethylase FBXL11 and BCL6 corepressor inhibits osteo/dentinogenic differentiation. Stem Cells 2013, 31, 126-136. [CrossRef] [PubMed]

74. Dong, R.; Yao, R.; Du, J.; Wang, S.; Fan, Z. Depletion of histone demethylase KDM2A enhanced the adipogenic and chondrogenic differentiation potentials of stem cells from apical papilla. Exp. Cell Res. 2013, 319, 2874-2882. [CrossRef] [PubMed]

75. Inagaki, T.; Iwasaki, S.; Matsumura, Y.; Kawamura, T.; Tanaka, T.; Abe, Y.; Yamasaki, A.; Tsurutani, Y.; Yoshida, A.; Chikaoka, Y.; et al. The FBXL10/KDM2B scaffolding protein associates with novel polycomb repressive complex-1 to regulate adipogenesis. J. Biol. Chem. 2015, 290, 4163-4177. [CrossRef] [PubMed] 
76. Meshorer, E.; Yellajoshula, D.; George, E.; Scambler, P.J.; Brown, D.T.; Misteli, T. Hyperdynamic plasticity of chromatin proteins in pluripotent embryonic stem cells. Dev. Cell 2006, 10, 105-116. [CrossRef] [PubMed]

77. Chambers, I.; Colby, D.; Robertson, M.; Nichols, J.; Lee, S.; Tweedie, S.; Smith, A. Functional expression cloning of nanog, a pluripotency sustaining factor in embryonic stem cells. Cell 2003, 113, 643-655. [CrossRef]

78. Ivanova, N.; Dobrin, R.; Lu, R.; Kotenko, I.; Levorse, J.; DeCoste, C.; Schafer, X.; Lun, Y.; Lemischka, I.R. Dissecting self-renewal in stem cells with RNA interference. Nature 2006, 442, 533-538. [CrossRef] [PubMed]

79. Matoba, R.; Niwa, H.; Masui, S.; Ohtsuka, S.; Carter, M.G.; Sharov, A.A.; Ko, M.S. Dissecting ОСТ3/4-regulated gene networks in embryonic stem cells by expression profiling. PLoS ONE 2006, 1, e26. [CrossRef] [PubMed]

80. Mitsui, K.; Tokuzawa, Y.; Itoh, H.; Segawa, K.; Murakami, M.; Takahashi, K.; Maruyama, M.; Maeda, M.; Yamanaka, $\mathrm{S}$. The homeoprotein nanog is required for maintenance of pluripotency in mouse epiblast and es cells. Cell 2003, 113, 631-642. [CrossRef]

81. Okada, Y.; Scott, G.; Ray, M.K.; Mishina, Y.; Zhang, Y. Histone demethylase JHDM2A is critical for TNP1 and PRM1 transcription and spermatogenesis. Nature 2007, 450, 119-123. [CrossRef] [PubMed]

82. Lockman, K.; Taylor, J.M.; Mack, C.P. The histone demethylase, JMJD1A, interacts with the myocardin factors to regulate SMC differentiation marker gene expression. Circ. Res. 2007, 101, e115-e123. [CrossRef] [PubMed]

83. Saez, M.A.; Fernandez-Rodriguez, J.; Moutinho, C.; Sanchez-Mut, J.V.; Gomez, A.; Vidal, E.; Petazzi, P.; Szczesna, K.; Lopez-Serra, P.; Lucariello, M.; et al. Mutations in JMJD1C are involved in rett syndrome and intellectual disability. Genet. Med. 2016, 18, 378-385. [CrossRef] [PubMed]

84. Verrier, L.; Escaffit, F.; Chailleux, C.; Trouche, D.; Vandromme, M. A new isoform of the histone demethylase JMJD2A/KDM4A is required for skeletal muscle differentiation. PLoS Genet. 2011, 7, e1001390. [CrossRef] [PubMed]

85. Ye, L.; Fan, Z.; Yu, B.; Chang, J.; Al Hezaimi, K.; Zhou, X.; Park, N.H.; Wang, C.Y. Histone demethylases KDM4B and KDM6B promotes osteogenic differentiation of human mscs. Cell Stem Cell 2012, 11, 50-61. [CrossRef] [PubMed]

86. Guo, L.; Li, X.; Huang, J.X.; Huang, H.Y.; Zhang, Y.Y.; Qian, S.W.; Zhu, H.; Zhang, Y.D.; Liu, Y.; Liu, Y.; et al. Histone demethylase $\mathrm{Kdm} 4 \mathrm{~b}$ functions as a co-factor of $\mathrm{c} /$ ebpbeta to promote mitotic clonal expansion during differentiation of 3t3-11 preadipocytes. Cell Death Differ. 2012, 19, 1917-1927. [CrossRef] [PubMed]

87. Lu, C.; Ward, P.S.; Kapoor, G.S.; Rohle, D.; Turcan, S.; Abdel-Wahab, O.; Edwards, C.R.; Khanin, R.; Figueroa, M.E.; Melnick, A.; et al. Idh mutation impairs histone demethylation and results in a block to cell differentiation. Nature 2012, 483, 474-478. [CrossRef] [PubMed]

88. Loh, Y.H.; Zhang, W.; Chen, X.; George, J.; Ng, H.H. Jmjd1a and jmjd2c histone H3 lys 9 demethylases regulate self-renewal in embryonic stem cells. Genes Dev. 2007, 21, 2545-2557. [CrossRef] [PubMed]

89. Iwamori, N.; Zhao, M.; Meistrich, M.L.; Matzuk, M.M. The testis-enriched histone demethylase, KDM4D, regulates methylation of histone $\mathrm{H} 3$ lysine 9 during spermatogenesis in the mouse but is dispensable for fertility. Biol. Reprod. 2011, 84, 1225-1234. [CrossRef] [PubMed]

90. Zhu, Y.; van Essen, D.; Saccani, S. Cell-type-specific control of enhancer activity by H3K9 trimethylation. Mol. Cell 2012, 46, 408-423. [CrossRef] [PubMed]

91. Zoabi, M.; Nadar-Ponniah, P.T.; Khoury-Haddad, H.; Usaj, M.; Budowski-Tal, I.; Haran, T.; Henn, A.; Mandel-Gutfreund, Y.; Ayoub, N. RNA-dependent chromatin localization of KDM4D lysine demethylase promotes H3K9me3 demethylation. Nucleic Acids Res. 2014, 42, 13026-13038. [CrossRef] [PubMed]

92. Christensen, J.; Agger, K.; Cloos, P.A.; Pasini, D.; Rose, S.; Sennels, L.; Rappsilber, J.; Hansen, K.H.; Salcini, A.E.; Helin, K. Rbp2 belongs to a family of demethylases, specific for tri-and dimethylated lysine 4 on histone 3. Cell 2007, 128, 1063-1076. [CrossRef] [PubMed]

93. Benevolenskaya, E.V.; Murray, H.L.; Branton, P.; Young, R.A.; Kaelin, W.G., Jr. Binding of pRB to the PHD protein RBP2 promotes cellular differentiation. Mol. Cell 2005, 18, 623-635. [CrossRef] [PubMed]

94. Ge, W.; Shi, L.; Zhou, Y.; Liu, Y.; Ma, G.E.; Jiang, Y.; Xu, Y.; Zhang, X.; Feng, H. Inhibition of osteogenic differentiation of human adipose-derived stromal cells by retinoblastoma binding protein 2 repression of RUNX2-activated transcription. Stem Cells 2011, 29, 1112-1125. [CrossRef] [PubMed]

95. Cloos, P.A.; Christensen, J.; Agger, K.; Helin, K. Erasing the methyl mark: Histone demethylases at the center of cellular differentiation and disease. Genes Dev. 2008, 22, 1115-1140. [CrossRef] [PubMed] 
96. Tan, K.; Shaw, A.L.; Madsen, B.; Jensen, K.; Taylor-Papadimitriou, J.; Freemont, P.S. Human PLU-1 has transcriptional repression properties and interacts with the developmental transcription factors BF-1 and PAX9. J. Biol. Chem. 2003, 278, 20507-20513. [CrossRef] [PubMed]

97. Jensen, L.R.; Bartenschlager, H.; Rujirabanjerd, S.; Tzschach, A.; Numann, A.; Janecke, A.R.; Sporle, R.; Stricker, S.; Raynaud, M.; Nelson, J.; et al. A distinctive gene expression fingerprint in mentally retarded male patients reflects disease-causing defects in the histone demethylase KDM5C. Pathogenetics 2010, 3, 2. [CrossRef] [PubMed]

98. Morales Torres, C.; Laugesen, A.; Helin, K. Utx is required for proper induction of ectoderm and mesoderm during differentiation of embryonic stem cells. PLOS ONE 2013, 8, e60020.

99. Wang, C.; Lee, J.E.; Cho, Y.W.; Xiao, Y.; Jin, Q.; Liu, C.; Ge, K. Utx regulates mesoderm differentiation of embryonic stem cells independent of H3K27 demethylase activity. Proc. Natl. Acad. Sci. USA 2012, 109, 15324-15329. [CrossRef] [PubMed]

100. Agger, K.; Cloos, P.A.; Rudkjaer, L.; Williams, K.; Andersen, G.; Christensen, J.; Helin, K. The H3K27me3 demethylase JMJD3 contributes to the activation of the INK4A-ARF locus in response to oncogene- and stress-induced senescence. Genes Dev. 2009, 23, 1171-1176. [CrossRef] [PubMed]

101. Barradas, M.; Anderton, E.; Acosta, J.C.; Li, S.; Banito, A.; Rodriguez-Niedenfuhr, M.; Maertens, G.; Banck, M.; Zhou, M.M.; Walsh, M.J.; et al. Histone demethylase JMJD3 contributes to epigenetic control of INK4A/ARF by oncogenic ras. Genes Dev. 2009, 23, 1177-1182. [CrossRef] [PubMed]

102. Zhao, W.; Li, Q.; Ayers, S.; Gu, Y.; Shi, Z.; Zhu, Q.; Chen, Y.; Wang, H.Y.; Wang, R.F. Jmjd3 inhibits reprogramming by upregulating expression of ink4a/arf and targeting phf20 for ubiquitination. Cell 2013, 152, 1037-1050. [CrossRef] [PubMed]

103. Hemming, S.; Cakouros, D.; Isenmann, S.; Cooper, L.; Menicanin, D.; Zannettino, A.; Gronthos, S. EZH2 and KDM6A act as an epigenetic switch to regulate mesenchymal stem cell lineage specification. Stem Cells 2014, 32, 802-815. [CrossRef] [PubMed]

104. Xu, J.; Yu, B.; Hong, C.; Wang, C.Y. KDM6B epigenetically regulates odontogenic differentiation of dental mesenchymal stem cells. Int. J. Oral Sci. 2013, 5, 200-205. [CrossRef] [PubMed]

105. Shpargel, K.B.; Sengoku, T.; Yokoyama, S.; Magnuson, T. UTX and UTY demonstrate histone demethylase-independent function in mouse embryonic development. PLoS Genet. 2012, 8, e1002964. [CrossRef] [PubMed]

106. Park, S.Y.; Park, J.W.; Chun, Y.S. Jumonji histone demethylases as emerging therapeutic targets. Pharmacol. Res. 2016, 105, 146-151. [CrossRef] [PubMed]

107. Ramos, C.; Robert, B. MSH/MSX gene family in neural development. Trends Genet. 2005, 21, $624-632$. [CrossRef] [PubMed]

108. Huang, C.; Xiang, Y.; Wang, Y.; Li, X.; Xu, L.; Zhu, Z.; Zhang, T.; Zhu, Q.; Zhang, K.; Jing, N.; et al. Dual-specificity histone demethylase KIAA1718 (KDM7A) regulates neural differentiation through FGF4. Cell Res. 2010, 20, 154-165. [CrossRef] [PubMed]

109. Kim, H.J.; Park, J.W.; Lee, K.H.; Yoon, H.; Shin, D.H.; Ju, U.I.; Seok, S.H.; Lim, S.H.; Lee, Z.H.; Kim, H.H.; et al. Plant homeodomain finger protein 2 promotes bone formation by demethylating and activating run 2 for osteoblast differentiation. Cell Res. 2014, 24, 1231-1249. [CrossRef] [PubMed]

110. Cheng, Z.; Cheung, P.; Kuo, A.J.; Yukl, E.T.; Wilmot, C.M.; Gozani, O.; Patel, D.J. A molecular threading mechanism underlies jumonji lysine demethylase KDM2A regulation of methylated H3K36. Genes Dev. 2014, 28, 1758-1771. [CrossRef] [PubMed]

111. Frescas, D.; Guardavaccaro, D.; Kuchay, S.M.; Kato, H.; Poleshko, A.; Basrur, V.; Elenitoba-Johnson, K.S.; Katz, R.A.; Pagano, M. KDM2A represses transcription of centromeric satellite repeats and maintains the heterochromatic state. Cell Cycle 2008, 7, 3539-3547. [CrossRef] [PubMed]

112. Lu, T.; Jackson, M.W.; Wang, B.; Yang, M.; Chance, M.R.; Miyagi, M.; Gudkov, A.V.; Stark, G.R. Regulation of NF-kappaB by NSD1/FBXL11-dependent reversible lysine methylation of p65. Proc. Natl. Acad. Sci. USA 2010, 107, 46-51. [CrossRef] [PubMed]

113. Huang, Y.; Liu, Y.; Yu, L.; Chen, J.; Hou, J.; Cui, L.; Ma, D.; Lu, W. Histone demethylase KDM2A promotes tumor cell growth and migration in gastric cancer. Tumour Biol. 2015, 36, 271-278. [CrossRef] [PubMed]

114. Liu, H.; Liu, L.; Holowatyj, A.; Jiang, Y.; Yang, Z.Q. Integrated genomic and functional analyses of histone demethylases identify oncogenic KDM2A isoform in breast cancer. Mol. Carcinog. 2016, 55, 977-990. [CrossRef] [PubMed] 
115. Wagner, K.W.; Alam, H.; Dhar, S.S.; Giri, U.; Li, N.; Wei, Y.; Giri, D.; Cascone, T.; Kim, J.H.; Ye, Y.; et al. KDM2A promotes lung tumorigenesis by epigenetically enhancing erk1/2 signaling. J. Clin. Investig. 2013, 123, 5231-5246. [CrossRef] [PubMed]

116. Rizwani, W.; Schaal, C.; Kunigal, S.; Coppola, D.; Chellappan, S. Mammalian lysine histone demethylase KDM2a regulates E2F1-mediated gene transcription in breast cancer cells. PLoS ONE 2014, 9, e100888. [CrossRef] [PubMed]

117. Suzuki, T.; Minehata, K.; Akagi, K.; Jenkins, N.A.; Copeland, N.G. Tumor suppressor gene identification using retroviral insertional mutagenesis in blm-deficient mice. EMBO J. 2006, 25, 3422-3431. [CrossRef] [PubMed]

118. Tzatsos, A.; Paskaleva, P.; Ferrari, F.; Deshpande, V.; Stoykova, S.; Contino, G.; Wong, K.K.; Lan, F.; Trojer, P.; Park, P.J.; et al. KDM2B promotes pancreatic cancer via polycomb-dependent and -independent transcriptional programs. J. Clin. Investig. 2013, 123, 727-739. [CrossRef] [PubMed]

119. He, J.; Nguyen, A.T.; Zhang, Y. Kdm2b/jhdm1b, an H3K36me2-specific demethylase, is required for initiation and maintenance of acute myeloid leukemia. Blood 2011, 117, 3869-3880. [CrossRef] [PubMed]

120. Gumz, M.L.; Zou, H.; Kreinest, P.A.; Childs, A.C.; Belmonte, L.S.; LeGrand, S.N.; Wu, K.J.; Luxon, B.A.; Sinha, M.; Parker, A.S.; et al. Secreted frizzled-related protein 1 loss contributes to tumor phenotype of clear cell renal cell carcinoma. Clin. Cancer Res. 2007, 13, 4740-4749. [CrossRef] [PubMed]

121. Uemura, M.; Yamamoto, H.; Takemasa, I.; Mimori, K.; Hemmi, H.; Mizushima, T.; Ikeda, M.; Sekimoto, M.; Matsuura, N.; Doki, Y.; et al. Jumonji domain containing 1a is a novel prognostic marker for colorectal cancer: In vivo identification from hypoxic tumor cells. Clin. Cancer Res. 2010, 16, 4636-4646. [CrossRef] [PubMed]

122. Wade, M.A.; Jones, D.; Wilson, L.; Stockley, J.; Coffey, K.; Robson, C.N.; Gaughan, L. The histone demethylase enzyme KDM3A is a key estrogen receptor regulator in breast cancer. Nucleic Acids Res. 2015, 43, 196-207. [CrossRef] [PubMed]

123. Krieg, A.J.; Rankin, E.B.; Chan, D.; Razorenova, O.; Fernandez, S.; Giaccia, A.J. Regulation of the histone demethylase JMJD1A by hypoxia-inducible factor 1 alpha enhances hypoxic gene expression and tumor growth. Mol. Cell. Biol. 2010, 30, 344-353. [CrossRef] [PubMed]

124. Zhu, N.; Chen, M.; Eng, R.; DeJong, J.; Sinha, A.U.; Rahnamay, N.F.; Koche, R.; Al-Shahrour, F.; Minehart, J.C.; Chen, C.W.; et al. MLL-AF9- and HOXA9-mediated acute myeloid leukemia stem cell self-renewal requires JMJD1C. J. Clin. Investig. 2016, 126, 997-1011. [CrossRef] [PubMed]

125. Wolf, S.S.; Patchev, V.K.; Obendorf, M. A novel variant of the putative demethylase gene, s-JMJD1C, is a coactivator of the AR. Arch. Biochem. Biophys. 2007, 460, 56-66. [CrossRef] [PubMed]

126. Cloos, P.A.; Christensen, J.; Agger, K.; Maiolica, A.; Rappsilber, J.; Antal, T.; Hansen, K.H.; Helin, K. The putative oncogene GASC1 demethylates tri- and dimethylated lysine 9 on histone H3. Nature 2006, 442, 307-311. [CrossRef] [PubMed]

127. Ehrbrecht, A.; Muller, U.; Wolter, M.; Hoischen, A.; Koch, A.; Radlwimmer, B.; Actor, B.; Mincheva, A.; Pietsch, T.; Lichter, P.; et al. Comprehensive genomic analysis of desmoplastic medulloblastomas: Identification of novel amplified genes and separate evaluation of the different histological components. J. Pathol. 2006, 208, 554-563. [CrossRef] [PubMed]

128. Liu, G.; Bollig-Fischer, A.; Kreike, B.; van de Vijver, M.J.; Abrams, J.; Ethier, S.P.; Yang, Z.Q. Genomic amplification and oncogenic properties of the GASC1 histone demethylase gene in breast cancer. Oncogene 2009, 28, 4491-4500. [CrossRef] [PubMed]

129. Uimonen, K.; Merikallio, H.; Paakko, P.; Harju, T.; Mannermaa, A.; Palvimo, J.; Kosma, V.M.; Soini, Y. GASC1 expression in lung carcinoma is associated with smoking and prognosis of squamous cell carcinoma. Histol. Histopathol. 2014, 29, 797-804. [PubMed]

130. Yang, Z.Q.; Imoto, I.; Fukuda, Y.; Pimkhaokham, A.; Shimada, Y.; Imamura, M.; Sugano, S.; Nakamura, Y.; Inazawa, J. Identification of a novel gene, GASC1, within an amplicon at 9p23-24 frequently detected in esophageal cancer cell lines. Cancer Res. 2000, 60, 4735-4739. [PubMed]

131. Hu, C.E.; Liu, Y.C.; Zhang, H.D.; Huang, G.J. JMJD2A predicts prognosis and regulates cell growth in human gastric cancer. Biochem. Biophys. Res. Commun. 2014, 449, 1-7. [CrossRef] [PubMed]

132. Teng, Y.C.; Lee, C.F.; Li, Y.S.; Chen, Y.R.; Hsiao, P.W.; Chan, M.Y.; Lin, F.M.; Huang, H.D.; Chen, Y.T.; Jeng, Y.M.; et al. Histone demethylase rbp2 promotes lung tumorigenesis and cancer metastasis. Cancer Res. 2013, 73, 4711-4721. [CrossRef] [PubMed] 
133. Zeng, J.; Ge, Z.; Wang, L.; Li, Q.; Wang, N.; Bjorkholm, M.; Jia, J.; Xu, D. The histone demethylase rbp2 is overexpressed in gastric cancer and its inhibition triggers senescence of cancer cells. Gastroenterology 2010, 138, 981-992. [CrossRef] [PubMed]

134. Roesch, A.; Becker, B.; Meyer, S.; Wild, P.; Hafner, C.; Landthaler, M.; Vogt, T. Retinoblastoma-binding protein 2-homolog 1: A retinoblastoma-binding protein downregulated in malignant melanomas. Mod. Pathol. 2005, 18, 1249-1257. [CrossRef] [PubMed]

135. Barrett, A.; Madsen, B.; Copier, J.; Lu, P.J.; Cooper, L.; Scibetta, A.G.; Burchell, J.; Taylor-Papadimitriou, J. Plu-1 nuclear protein, which is upregulated in breast cancer, shows restricted expression in normal human adult tissues: A new cancer/testis antigen? Int. J. Cancer 2002, 101, 581-588. [CrossRef] [PubMed]

136. Lu, P.J.; Sundquist, K.; Baeckstrom, D.; Poulsom, R.; Hanby, A.; Meier-Ewert, S.; Jones, T.; Mitchell, M.; Pitha-Rowe, P.; Freemont, P.; et al. A novel gene (plu-1) containing highly conserved putative DNA/chromatin binding motifs is specifically up-regulated in breast cancer. J. Biol. Chem. 1999, 274, 15633-15645. [CrossRef] [PubMed]

137. Tang, B.; Qi, G.; Tang, F.; Yuan, S.; Wang, Z.; Liang, X.; Li, B.; Yu, S.; Liu, J.; Huang, Q.; et al. Jarid1b promotes metastasis and epithelial-mesenchymal transition via pten/akt signaling in hepatocellular carcinoma cells. Oncotarget 2015, 6, 12723-12739. [CrossRef] [PubMed]

138. Xiang, Y.; Zhu, Z.; Han, G.; Ye, X.; Xu, B.; Peng, Z.; Ma, Y.; Yu, Y.; Lin, H.; Chen, A.P.; et al. Jarid1b is a histone h3 lysine 4 demethylase up-regulated in prostate cancer. Proc. Natl. Acad. Sci. USA 2007, 104, 19226-19231. [CrossRef] [PubMed]

139. Wang, D.; Han, S.; Peng, R.; Jiao, C.; Wang, X.; Yang, X.; Yang, R.; Li, X. Depletion of histone demethylase KDM5B inhibits cell proliferation of hepatocellular carcinoma by regulation of cell cycle checkpoint proteins p15 and p27. J. Exp. Clin. Cancer Res. 2016, 35, 37. [CrossRef] [PubMed]

140. Stein, J.; Majores, M.; Rohde, M.; Lim, S.; Schneider, S.; Krappe, E.; Ellinger, J.; Dietel, M.; Stephan, C.; Jung, K.; et al. KDM5C is overexpressed in prostate cancer and is a prognostic marker for prostate-specific antigen-relapse following radical prostatectomy. Am. J. Pathol. 2014, 184, 2430-2437. [CrossRef] [PubMed]

141. Rondinelli, B.; Rosano, D.; Antonini, E.; Frenquelli, M.; Montanini, L.; Huang, D.; Segalla, S.; Yoshihara, K.; Amin, S.B.; Lazarevic, D.; et al. Histone demethylase JARID1c inactivation triggers genomic instability in sporadic renal cancer. J. Clin. Investig. 2015, 125, 4625-4637. [CrossRef] [PubMed]

142. Dalgliesh, G.L.; Furge, K.; Greenman, C.; Chen, L.; Bignell, G.; Butler, A.; Davies, H.; Edkins, S.; Hardy, C.; Latimer, C.; et al. Systematic sequencing of renal carcinoma reveals inactivation of histone modifying genes. Nature 2010, 463, 360-363. [CrossRef] [PubMed]

143. Gui, Y.; Guo, G.; Huang, Y.; Hu, X.; Tang, A.; Gao, S.; Wu, R.; Chen, C.; Li, X.; Zhou, L.; et al. Frequent mutations of chromatin remodeling genes in transitional cell carcinoma of the bladder. Nat. Genet. 2011, 43, 875-878. [CrossRef] [PubMed]

144. Ntziachristos, P.; Tsirigos, A.; Welstead, G.G.; Trimarchi, T.; Bakogianni, S.; Xu, L.; Loizou, E.; Holmfeldt, L.; Strikoudis, A.; King, B.; et al. Contrasting roles of histone 3 lysine 27 demethylases in acute lymphoblastic leukaemia. Nature 2014, 514, 513-517. [CrossRef] [PubMed]

145. Van Haaften, G.; Dalgliesh, G.L.; Davies, H.; Chen, L.; Bignell, G.; Greenman, C.; Edkins, S.; Hardy, C.; O'Meara, S.; Teague, J.; et al. Somatic mutations of the histone H3K27 demethylase gene utx in human cancer. Nat. Genet. 2009, 41, 521-523. [CrossRef] [PubMed]

146. Pereira, F.; Barbachano, A.; Silva, J.; Bonilla, F.; Campbell, M.J.; Munoz, A.; Larriba, M.J. KDM6B/JMJD3 histone demethylase is induced by vitamin $\mathrm{d}$ and modulates its effects in colon cancer cells. Hum. Mol. Genet. 2011, 20, 4655-4665. [CrossRef] [PubMed]

147. Tokunaga, R.; Nakagawa, S.; Sakamoto, Y.; Karashima, R.; Ida, S.; Imamura, Y.; Ishimoto, T.; Iwagami, S.; Baba, Y.; Miyamoto, Y.; et al. Abstract 5150: JMJD3 suppresses progression of colorectal carcinoma by regulating cell cycle and anti-apoptosis. Cancer Res. 2014, 74, 5150. [CrossRef]

148. Yamamoto, K.; Tateishi, K.; Kudo, Y.; Sato, T.; Yamamoto, S.; Miyabayashi, K.; Matsusaka, K.; Asaoka, Y.; Ijichi, H.; Hirata, Y.; et al. Loss of histone demethylase KDM6B enhances aggressiveness of pancreatic cancer through downregulation of C/EBPalpha. Carcinogenesis 2014, 35, 2404-2414. [CrossRef] [PubMed]

149. Anderton, J.A.; Bose, S.; Vockerodt, M.; Vrzalikova, K.; Wei, W.; Kuo, M.; Helin, K.; Christensen, J.; Rowe, M.; Murray, P.G.; et al. The H3K27me3 demethylase, KDM6B, is induced by epstein-barr virus and over-expressed in hodgkin's lymphoma. Oncogene 2011, 30, 2037-2043. [CrossRef] [PubMed] 
150. Park, W.Y.; Hong, B.J.; Lee, J.; Choi, C.; Kim, M.Y. H3k27 demethylase JMJD3 employs the NF-kappaB and bmp signaling pathways to modulate the tumor microenvironment and promote melanoma progression and metastasis. Cancer Res. 2016, 76, 161-170. [CrossRef] [PubMed]

151. Perrigue, P.M.; Najbauer, J.; Barciszewski, J. Histone demethylase JMJD3 at the intersection of cellular senescence and cancer. Biochim. Biophys. Acta 2016, 1865, 237-244. [CrossRef] [PubMed]

152. Ramadoss, S.; Chen, X.; Wang, C.Y. Histone demethylase KDM6B promotes epithelial-mesenchymal transition. J. Biol. Chem. 2012, 287, 44508-44517. [CrossRef] [PubMed]

153. Shen, Y.; Guo, X.; Wang, Y.; Qiu, W.; Chang, Y.; Zhang, A.; Duan, X. Expression and significance of histone H3K27 demethylases in renal cell carcinoma. BMC Cancer 2012, 12, 470. [CrossRef] [PubMed]

154. Wei, Y.; Chen, R.; Dimicoli, S.; Bueso-Ramos, C.; Neuberg, D.; Pierce, S.; Wang, H.; Yang, H.; Jia, Y.; Zheng, H.; et al. Global H3K4ME3 genome mapping reveals alterations of innate immunity signaling and overexpression of jmjd3 in human myelodysplastic syndrome CD34+ cells. Leukemia 2013, 27, 2177-2186. [CrossRef] [PubMed]

155. Xiang, Y.; Zhu, Z.; Han, G.; Lin, H.; Xu, L.; Chen, C.D. Jmjd3 is a histone h3k27 demethylase. Cell Res. 2007, 17, 850-857. [CrossRef] [PubMed]

156. Li, Q.; Hou, L.; Ding, G.; Li, Y.; Wang, J.; Qian, B.; Sun, J.; Wang, Q. Kdm6b induces epithelial-mesenchymal transition and enhances clear cell renal cell carcinoma metastasis through the activation of slug. Int. J. Clin. Exp. Pathol. 2015, 8, 6334-6344. [PubMed]

157. Sun, X.; Qiu, J.J.; Zhu, S.; Cao, B.; Sun, L.; Li, S.; Li, P.; Zhang, S.; Dong, S. Oncogenic features of phf8 histone demethylase in esophageal squamous cell carcinoma. PLoS ONE 2013, 8, e77353. [CrossRef] [PubMed]

158. Bjorkman, M.; Ostling, P.; Harma, V.; Virtanen, J.; Mpindi, J.P.; Rantala, J.; Mirtti, T.; Vesterinen, T.; Lundin, M.; Sankila, A.; et al. Systematic knockdown of epigenetic enzymes identifies a novel histone demethylase PHF8 overexpressed in prostate cancer with an impact on cell proliferation, migration and invasion. Oncogene 2012, 31, 3444-3456. [CrossRef] [PubMed]

159. Asensio-Juan, E.; Gallego, C.; Martinez-Balbas, M.A. The histone demethylase PHF8 is essential for cytoskeleton dynamics. Nucleic Acids Res. 2012, 40, 9429-9440. [CrossRef] [PubMed]

160. Lim, H.J.; Dimova, N.V.; Tan, M.K.; Sigoillot, F.D.; King, R.W.; Shi, Y. The G2/M regulator histone demethylase PHF8 is targeted for degradation by the anaphase-promoting complex containing CDC20. Mol. Cell. Biol. 2013, 33, 4166-4180. [CrossRef] [PubMed]

161. Qi, H.H.; Sarkissian, M.; Hu, G.Q.; Wang, Z.; Bhattacharjee, A.; Gordon, D.B.; Gonzales, M.; Lan, F.; Ongusaha, P.P.; Huarte, M.; et al. Histone H4K20/H3K9 demethylase PHF8 regulates zebrafish brain and craniofacial development. Nature 2010, 466, 503-507. [CrossRef] [PubMed]

162. Wang, J.; Lin, X.; Wang, S.; Wang, C.; Wang, Q.; Duan, X.; Lu, P.; Wang, Q.; Wang, C.; Liu, X.S.; et al. PHF8 and REST/NRSF co-occupy gene promoters to regulate proximal gene expression. Sci. Rep. 2014, 4, 5008. [CrossRef] [PubMed]

163. Arteaga, M.F.; Mikesch, J.H.; Qiu, J.; Christensen, J.; Helin, K.; Kogan, S.C.; Dong, S.; So, C.W. The histone demethylase PHF8 governs retinoic acid response in acute promyelocytic leukemia. Cancer Cell 2013, 23, 376-389. [CrossRef] [PubMed]

164. Lee, K.H.; Park, J.W.; Sung, H.S.; Choi, Y.J.; Kim, W.H.; Lee, H.S.; Chung, H.J.; Shin, H.W.; Cho, C.H.; Kim, T.Y.; et al. PHF2 histone demethylase acts as a tumor suppressor in association with p53 in cancer. Oncogene 2015, 34, 2897-2909. [CrossRef] [PubMed]

165. Williamson, P.R.; Kagan, H.M. Reaction pathway of bovine aortic lysyl oxidase. J. Biol. Chem. 1986, 261, 9477-9482. [PubMed]

166. Barker, H.E.; Cox, T.R.; Erler, J.T. The rationale for targeting the lox family in cancer. Nat. Rev. Cancer 2012, 12, 540-552. [CrossRef] [PubMed]

167. Siegel, R.C. Biosynthesis of collagen crosslinks: Increased activity of purified lysyl oxidase with reconstituted collagen fibrils. Proc. Natl. Acad. Sci. USA 1974, 71, 4826-4830. [CrossRef] [PubMed]

168. Barker, H.E.; Chang, J.; Cox, T.R.; Lang, G.; Bird, D.; Nicolau, M.; Evans, H.R.; Gartland, A.; Erler, J.T. Loxl2-mediated matrix remodeling in metastasis and mammary gland involution. Cancer Res. 2011, 71, 1561-1572. [CrossRef] [PubMed]

169. Herranz, N.; Dave, N.; Millanes-Romero, A.; Pascual-Reguant, L.; Morey, L.; Diaz, V.M.; Lorenz-Fonfria, V.; Gutierrez-Gallego, R.; Jeronimo, C.; Iturbide, A.; et al. Lysyl oxidase-like 2 (loxl2) oxidizes trimethylated lysine 4 in histone H3. FEBS J. 2016, 283, 4263-4273. [CrossRef] [PubMed] 
170. Wang, S.X.; Mure, M.; Medzihradszky, K.F.; Burlingame, A.L.; Brown, D.E.; Dooley, D.M.; Smith, A.J.; Kagan, H.M.; Klinman, J.P. A crosslinked cofactor in lysyl oxidase: Redox function for amino acid side chains. Science 1996, 273, 1078-1084. [CrossRef] [PubMed]

171. Fujimoto, E.; Tajima, S. Reciprocal regulation of lox and loxl2 expression during cell adhesion and terminal differentiation in epidermal keratinocytes. J. Dermatol. Sci. 2009, 55, 91-98. [CrossRef] [PubMed]

172. Slaga, T.J.; Budunova, I.V.; Gimenez-Conti, I.B.; Aldaz, C.M. The mouse skin carcinogenesis model. J. Investig. Dermatol. Symp. Proc. 1996, 1, 151-156. [PubMed]

173. Kim, J.H.; Lee, E.H.; Park, H.J.; Park, E.K.; Kwon, T.G.; Shin, H.I.; Cho, J.Y. The role of lysyl oxidase-like 2 in the odontogenic differentiation of human dental pulp stem cells. Mol. Cells 2013, 35, 543-549. [CrossRef] [PubMed]

174. Iftikhar, M.; Hurtado, P.; Bais, M.V.; Wigner, N.; Stephens, D.N.; Gerstenfeld, L.C.; Trackman, P.C. Lysyl oxidase-like-2 (loxl2) is a major isoform in chondrocytes and is critically required for differentiation. J. Biol. Chem. 2011, 286, 909-918. [CrossRef] [PubMed]

175. Iturbide, A.; Pascual-Reguant, L.; Fargas, L.; Cebria, J.P.; Alsina, B.; Garcia de Herreros, A.; Peiro, S. LOXL2 oxidizes methylated TAF10 and controls TFIID-dependent genes during neural progenitor differentiation. Mol. Cell 2015, 58, 755-766. [CrossRef] [PubMed]

176. Schietke, R.; Warnecke, C.; Wacker, I.; Schodel, J.; Mole, D.R.; Campean, V.; Amann, K.; Goppelt-Struebe, M.; Behrens, J.; Eckardt, K.U.; et al. The lysyl oxidases LOX and LOXL2 are necessary and sufficient to repress E-cadherin in hypoxia: Insights into cellular transformation processes mediated by HIF-1. J. Biol. Chem. 2010, 285, 6658-6669. [CrossRef] [PubMed]

177. Voloshenyuk, T.G.; Landesman, E.S.; Khoutorova, E.; Hart, A.D.; Gardner, J.D. Induction of cardiac fibroblast lysyl oxidase by TGF-Beta1 requires PI3K/AKT, SMAD3, and MAPK signaling. Cytokine 2011, 55, 90-97. [CrossRef] [PubMed]

178. Barry-Hamilton, V.; Spangler, R.; Marshall, D.; McCauley, S.; Rodriguez, H.M.; Oyasu, M.; Mikels, A.; Vaysberg, M.; Ghermazien, H.; Wai, C.; et al. Allosteric inhibition of lysyl oxidase-like-2 impedes the development of a pathologic microenvironment. Nat. Med. 2010, 16, 1009-1017. [CrossRef] [PubMed]

179. Peng, L.; Ran, Y.L.; Hu, H.; Yu, L.; Liu, Q.; Zhou, Z.; Sun, Y.M.; Sun, L.C.; Pan, J.; Sun, L.X.; et al. Secreted LOXL2 is a novel therapeutic target that promotes gastric cancer metastasis via the SRC/FAK pathway. Carcinogenesis 2009, 30, 1660-1669. [CrossRef] [PubMed]

180. Wong, C.C.; Tse, A.P.; Huang, Y.P.; Zhu, Y.T.; Chiu, D.K.; Lai, R.K.; Au, S.L.; Kai, A.K.; Lee, J.M.; Wei, L.L.; et al. Lysyl oxidase-like 2 is critical to tumor microenvironment and metastatic niche formation in hepatocellular carcinoma. Hepatology 2014, 60, 1645-1658. [CrossRef] [PubMed]

181. Huang, J.; Sengupta, R.; Espejo, A.B.; Lee, M.G.; Dorsey, J.A.; Richter, M.; Opravil, S.; Shiekhattar, R.; Bedford, M.T.; Jenuwein, T.; et al. P53 is regulated by the lysine demethylase lsd1. Nature 2007, 449, 105-108. [CrossRef] [PubMed]

182. Wang, J.; Hevi, S.; Kurash, J.K.; Lei, H.; Gay, F.; Bajko, J.; Su, H.; Sun, W.; Chang, H.; Xu, G.; et al. The lysine demethylasE LSD1 (KDM1) is required for maintenance of global DNA methylation. Nat. Genet. 2009, 41, 125-129. [CrossRef] [PubMed]

183. Sola, S.; Xavier, J.M.; Santos, D.M.; Aranha, M.M.; Morgado, A.L.; Jepsen, K.; Rodrigues, C.M. P53 interaction with JMJD3 results in its nuclear distribution during mouse neural stem cell differentiation. PLoS ONE 2011, 6, e18421. [CrossRef] [PubMed]

184. Kontaki, H.; Talianidis, I. Lysine methylation regulates E2F1-induced cell death. Mol. Cell 2010, 39, $152-160$. [CrossRef] [PubMed]

185. Cho, H.S.; Suzuki, T.; Dohmae, N.; Hayami, S.; Unoki, M.; Yoshimatsu, M.; Toyokawa, G.; Takawa, M.; Chen, T.; Kurash, J.K.; et al. Demethylation of Rb regulator MYPT1 by histone demethylase LSD1 promotes cell cycle progression in cancer cells. Cancer Res. 2011, 71, 655-660. [CrossRef] [PubMed]

186. Hoesel, B.; Schmid, J.A. The complexity of NF-kappaB signaling in inflammation and cancer. Mol. Cancer 2013, 12, 86. [CrossRef] [PubMed]

187. Farcas, A.M.; Blackledge, N.P.; Sudbery, I.; Long, H.K.; McGouran, J.F.; Rose, N.R.; Lee, S.; Sims, D.; Cerase, A.; Sheahan, T.W.; et al. KDM2B links the Polycomb Repressive Complex 1 (PRC1) to recognition of CpG islands. eLife 2012, 1, e00205. [CrossRef] [PubMed]

188. Long, H.K.; Blackledge, N.P.; Klose, R.J. Zf-cxxc domain-containing proteins, CpG islands and the chromatin connection. Biochem. Soc. Trans. 2013, 41, 727-740. [CrossRef] [PubMed] 
189. He, J.; Shen, L.; Wan, M.; Taranova, O.; Wu, H.; Zhang, Y. KDM2B maintains murine embryonic stem cell status by recruiting PRC1 complex to cpg islands of developmental genes. Nat. Cell Biol. 2013, 15, 373-384. [CrossRef] [PubMed]

190. Abe, Y.; Rozqie, R.; Matsumura, Y.; Kawamura, T.; Nakaki, R.; Tsurutani, Y.; Tanimura-Inagaki, K.; Shiono, A.; Magoori, K.; Nakamura, K.; et al. JMJD1A is a signal-sensing scaffold that regulates acute chromatin dynamics via SWI/SNF association for thermogenesis. Nature Commun. 2015, 6, 7052. [CrossRef] [PubMed]

191. Miller, S.A.; Mohn, S.E.; Weinmann, A.S. Jmjd3 and UTX play a demethylase-independent role in chromatin remodeling to regulate T-box family member-dependent gene expression. Mol. Cell 2010, 40, 594-605. [CrossRef] [PubMed]

(C) 2017 by the authors. Licensee MDPI, Basel, Switzerland. This article is an open access article distributed under the terms and conditions of the Creative Commons Attribution (CC BY) license (http:/ / creativecommons.org/licenses/by/4.0/). 